\title{
Cabozantinib and Tivantinib, but Not INC280, Induce Antiproliferative and Antimigratory Effects in Human Neuroendocrine Tumor Cells in vitro: Evidence for 'Off-Target' Effects Not Mediated by c-Met Inhibition
}

\author{
Clemens Reuther ${ }^{\mathrm{a}}$ Vera Heinzle ${ }^{\mathrm{a}}$ Matilde Spampatti ${ }^{\mathrm{a}, \mathrm{c}}$ George Vlotides ${ }^{\mathrm{a}}$ \\ Enrico de Toni ${ }^{a} \quad$ Gerald Spöttl $^{\mathrm{a}} \quad$ Julian Maurer ${ }^{\mathrm{a}}$ Svenja Nölting ${ }^{\mathrm{a}}$ Burkhard Göke ${ }^{\mathrm{a}, \mathrm{b}}$ \\ Christoph J. Auernhammer ${ }^{\mathrm{a}}$ \\ ${ }^{a}$ Department of Internal Medicine II, Campus Grosshadern, University Hospital, Ludwig Maximilian University of

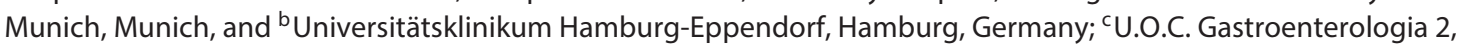 \\ Fondazione IRCCS Cà Granda Ospedale Maggiore Policlinico and Università degli Studi di Milano, Milan, Italy
}

\author{
Key Words \\ c-Met $\cdot$ INC280 $\cdot$ Cabozantinib $\cdot$ Tivantinib $\cdot$ Neuroendocrine \\ tumor
}

\begin{abstract}
Background/Aims: The hepatocyte growth factor/transmembrane tyrosine kinase receptor c-Met has been defined as a potential target in antitumoral treatment of various carcinomas. We aimed to investigate the direct effect of c-Met inhibition on neuroendocrine tumor cells in vitro. Methods: The effects of the multi-tyrosine kinase inhibitors cabozantinib and tivantinib and of the highly specific c-Met inhibitor INC280 were investigated in human pancreatic neuroendocrine BON1, bronchopulmonary NCl-H727 and midgut GOT1 cells in vitro. Results: INC280, cabozantinib and tivantinib inhibited c-Met phosphorylation, respectively. However, while equimolar concentrations $(10 \mu \mathrm{M})$ of cabozantinib and tivantinib inhibited cell viability and cell migration, INC280 had no inhibitory effect. Knockdown experiments with cMet siRNA also did not demonstrate effects on cell viability. Cabozantinib and tivantinib caused a G2 arrest in neuroendocrine tumor cells. Conclusions: Our in vitro data suggest
\end{abstract}

that c-Met inhibition alone is not sufficient to exert direct antitumoral or antimigratory effects in neuroendocrine tumor cells. The multi-tyrosine kinase inhibitors cabozantinib and tivantinib show promising antitumoral and antimigratory effects in neuroendocrine tumor cells, which are most probably 'off-target' effects, not mediated by c-Met.

(c) 2015 S. Karger AG, Basel

\section{Introduction}

Neuroendocrine tumors (NET) are a heterogeneous group of neoplasms mainly originating from the gastroenteropancreatic system and the lung [1]. Molecular targeted therapy of NETs with the mTOR inhibitor everolimus [2,3] or the multi-tyrosine kinase inhibitor (multiTKI) sunitinib (VEGFR, PDGFR, KIT) [4] is currently only approved for pancreatic NETs. There is still an unmet need for further medical therapies including novel targeted therapies $[5,6]$.

The hepatocyte growth factor (HGF) receptor is encoded by the proto-oncogen c-Met and is a transmembrane tyrosine kinase. The endogenous ligand of c-Met is

\section{KARGER}

E-Mail karger@karger.com

www.karger.com/nen
(C) 2015 S. Karger AG, Base

$0028-3835 / 15 / 1034-0383 \$ 39.50 / 0$
Christoph J. Auernhammer

Department of Internal Medicine II, Campus Grosshadern

University Hospital, GEPNET-KUM, Ludwig Maximilian University of Munich

Marchioninistrasse 15, DE-81377 Munich (Germany)

E-Mail christoph.auernhammer@med.uni-muenchen.de 
HGF. The HGF/c-Met axis has been characterized as an important target in cancer therapy [7-10] as it mediates tumor cell growth, migration and metastasis. Extracellular anti-HGF antibodies, anti-Met antibodies, as well as ATP-competitive and non-ATP competitive MET inhibitors have been developed and are in clinical trial programs [7, 9]. Cabozantinib (XL-184) is an ATP-competitive multi-TKI (with activity against c-Met, VEGFR2, cKIT, FLT3, RET and TIE2) that has recentlybeen approved by the FDA and EMEA for the treatment of medullary thyroid carcinoma $[11,12]$. Cabozantinib is also currently in phase 3 clinical trials for hepatocellular carcinoma (NCT01908426), prostate cancer (NCT01522443) and renal cell carcinoma (NCT01865747). A phase 2 clinical trial with cabozantinib in patients with NET is currently ongoing (NCT01466036). Tivantinib (ARQ-197) is a non-ATP-competitive c-MET kinase inhibitor [7]. Recently, 'off-target' effects of tivantinib have been reported, and antitumoral effects of tivantinib irrespective of c-Met inhibition have been found in vitro [13-16]. Tivantinib has positive phase 2 trial results $[17,18]$, and current phase 3 clinical trials for hepatocellular carcinoma (NCT02029157) and for NSCLC (NCT01377376) are ongoing. INC280 (c-Met) is an ATP-competitive c-MET kinase inhibitor [7], currently in phase $1 / 2$ clinical trials in various cancer entities.

In preclinical pancreatic neuroendocrine tumor models, various multi-TKIs with combined anti-VEGF and anti-MET efficacy have shown enhanced angiogenesis inhibition, as well as suppression of tumor invasion and metastasis [19-21]. In the Rip-Tag2 mouse model [19], the multi-TKIs foretinib (XL880; with activity against cMet, VEGFR2, PDGFR, c-KIT, FLT3, RON and TIE2) and cabozantinib (XL184; with activity against c-Met, VEGFR2, c-KIT, FLT3, RET and TIE2), demonstrated superior inhibition of angiogenesis, reduced tumor invasiveness and reduced metastasis in comparison to the multi-TKI XL999 (with activity against VEGFR2, PDGFR, c-KIT and FLT3). This higher antitumoral efficacy of XL880 and XL184 compared to XL999 might have been caused by their different activities against c-Met with IC50s of 0.4 and 1.3 versus $463 \mathrm{~nm}$ [19]. Inhibition of VEGF signaling by an anti-VEGF antibody or by sunitinib in the RIP-Tag2 mouse model reduced tumor growth but caused an increase in phospho-c-Met expression, paralleled by increased lymphatic metastasis. Invasion and metastasis were reduced by the c-Met inhibitors PF04217903 (with activity against c-Met, ALK) and crizotinib (PF-02341066; with activity against c-Met and ALK) or cabozantinib (XL184; with activity against c-Met,
VEGFR2, c-KIT, FLT3, RET and TIE2) [20, 21]. Due to these findings, a role of c-Met as a potential target in neuroendocrine tumors has been suggested [19-21]. A phase 2 clinical trial with cabozantinib in patients with neuroendocrine tumors is currently ongoing (NCT01466036).

Despite these promising preclinical data for the multiTKI cabozantinib in neuroendocrine tumors [19-21], a direct effect of c-MET inhibition on neuroendocrine tumor cell growth and migration seems not yet proven. The multi-TKI tivantinib has recently been reported in various cancer cells to exert its antitumoral efficacy not related to c-Met inhibition but by other 'off-target' effects [13-16]. Therefore, we performed a comparative in vitro study using equimolar concentrations of the highly specific c-Met inhibitor INC280 and the multi-TKIs cabozantinib and tivantinib in several human neuroendocrine tumor cell lines. We compared the efficacy of all three compounds on c-Met phosphorylation status, cell viability, cell cycle control, as well as cell migration. In addition, we performed siRNA experiments to knockdown c-MET expression in neuroendocrine tumor cells. Our study demonstrates that c-Met inhibition is not essential for the inhibition of cell growth and cell migration in the investigated neuroendocrine tumor cell models. The observed antiproliferative and antimigratory effects of cabozantinib and tivantinib seem to be mediated by 'off-target' effects other than c-Met.

\section{Materials and Methods}

\section{Materials}

Dulbecco's modified Eagle medium - Nutrient Mixture F-12, 1:1 (DMEM/F12) - and penicillin/streptomycin were purchased from Gibco/Invitrogen (Karlsruhe, Germany), trypsin-EDTA $(10 \times)$ from PAA Laboratories (Cölbe, Germany), phosphate-buffered saline (PBS) and RPMI medium (with L-glutamine, $\mathrm{NaCO}_{3}$ ) were from Sigma-Aldrich (St. Louis, Mo., USA), and fetal bovine serum (FBS) and amphotericin B were acquired from Biochrom (Berlin, Germany). INC280 was from Novartis (Basel, Switzerland). Cabozantinib and tivantinib were from Selleckchem (Houston, Tex., USA).

\section{Cell Cultures}

All human neuroendocrine cell lines were received and cultured as recently described [22]. The human pancreatic neuroendocrine tumor cell line BON1 [23, 24] (kindly provided by Prof. R. Göke, Marburg, Germany) was grown in DMEM/F12 (1:1) supplemented with $10 \%$ FBS, $1 \%$ penicillin/streptomycin and $0.4 \%$ amphotericin B. The human midgut carcinoid GOT1 cells [25] (kindly provided by Prof. O. Nilsson, Sahlgrenska University Hospital Göteborg, Sweden) and human bronchopulmonary neuroendocrine NCI-H727 tumor cells [26, 27] (purchased from ATCC, Manassas, Va., USA) were cultured in RPMI medium supplement- 
ed with $10 \%$ FBS, $1 \%$ penicillin/streptomycin and $0.4 \%$ amphotericin $\mathrm{B}$. The cells were mycoplasma free and incubated at $37^{\circ} \mathrm{C}$ in $5 \% \mathrm{CO}_{2} / 95 \%$ air.

\section{Assessment of Cell Viability}

BON1 and NCI-H727 cells were counted by an automated cell counter (Countess ${ }^{\mathrm{TM}}$, Invitrogen, Germany), seeded into 96-well plates at densities of 3,000 (BON1) and 4,000 (NCI-H727) cells per well and grown for $24 \mathrm{~h}$ in a complete medium containing serum/ antibiotic. The next day, the cells were incubated with various concentrations of INC280, cabozantinib and tivantinib ( $1 \mathrm{nM}$ to 10 $\mu \mathrm{M}$ ) in $10 \%$ FBS medium (antibiotic free). After 24, 48 and $72 \mathrm{~h}$, the metabolic activity was measured with 'Cell Titer 96 Aqueous One Solution' cell proliferation assay (Promega, Madison, Wis., USA) according to the manufacturer's instructions. The measurement was performed at $492 \mathrm{~nm}$ with an ELISA plate reader.

\section{siRNA Transfection}

The siRNA transfections were performed as described previously [28]. The siRNA oligonucleotide [ON-TARGETplus SMARTpool, Human MET (4233), Cat. No. 003156-00-0005] and the nontargeting siRNA (ON-TARGETplus Non-targeting Pool, Cat. No. D-001810-10-05) were purchased from Thermo Fisher Scientific (Schwerte, Germany). Cells were transfected in an antibiotic- and FBS-free medium using DharmaFECT 2 (BON1) and Dharmafect 3 (NCI-H727) according to the manufacturer's instructions (Dharmacon, Lafayette, Colo., USA). Twenty-four hours after transfection, FBS was added for a final concentration of $10 \%$.

\section{Cell Cycle Analysis by FACS}

Cell cycle distribution was analyzed using propidium iodide staining and flow cytometry (BD Accuri C6 Analysis). Cells were cultured in 6-well plates $\left(4 \times 10^{5} \mathrm{BON} 1\right.$ cells/well and $5 \times 10^{5} \mathrm{NCI}$ $\mathrm{H} 727$ cells/well) for $24 \mathrm{~h}$ in complete medium. The next day, the medium was replaced with fresh $10 \%$ FBS medium and incubated with $10 \mu \mathrm{M}$ INC280, cabozantinib and tivantinib. After 24, 48 and $72 \mathrm{~h}$, cells were washed with PBS and treated with $300 \mu \mathrm{l}$ trypsin at $37^{\circ} \mathrm{C}$ for $4 \mathrm{~min}$. Cells were collected and centrifuged at 2,000 rpm for $5 \mathrm{~min}$. After another wash cycle with PBS, the cells were centrifuged again. The pellets were resuspended in $350 \mu \mathrm{l}$ propidium iodide. After $2 \mathrm{~h}$, the samples were measured.

\section{Cell Migration Assay}

BON1 and NCI-H727 cells were seeded at densities of $120,000 / 140,000$ cells/chamber in culture inserts (Ibidi, Munich, Germany). After $24 \mathrm{~h}$, the inserts were removed, and the cells were treated with $100 \mathrm{nM}$ and $10 \mu \mathrm{M}$ of INC280, cabozantinib and tivantinib. Every $24 \mathrm{~h}$, pictures of the gap between the two cell layers were taken [Zeiss, Axiovert 135 TV (microscope) and Zeiss, AxioCam MRm (camera)]. The assay was stopped after $72 \mathrm{~h}$, and pictures were analyzed.

\section{Protein Extraction and Western Blotting}

For Western blot experiments, $4 \times 10^{5}$ cells (BON1) or $5 \times 10^{5}$ cells (NCI-H727) were seeded in 6-well plates and grown for $24 \mathrm{~h}$ in complete medium. After the medium was replaced by a fresh $10 \%$ FBS medium, the cells were incubated with several concentrations of INC280, cabozantinib and tivantinib $(1 \mathrm{nM}$ to $10 \mu \mathrm{M})$ for 2 and $24 \mathrm{~h}$. The cells were placed on ice, washed twice with cold
PBS and lysed in $200 \mu$ lysis buffer $\left(\right.$ M-PER ${ }^{\circledR}$ Mammalian Protein Extraction Reagent containing HALT ${ }^{\mathrm{TM}}$ protease and phosphatase inhibitor cocktail; Thermo Scientific, Rockford, Ill., USA). Lysates were centrifuged at 13,000 rpm for $10 \mathrm{~min}$. The supernatants were adjusted to the same protein concentration (30-50 $\mu \mathrm{g} / 50 \mu \mathrm{l}$; Rotiquant Universal, Carl Roth, Karlsruhe, Germany). Sodium dodecyl sulfate (SDS) sample buffer ( $0.25 \mathrm{~mm}$ Tris HCL, $40 \%$ glycerol, $2 \%$ SDS, $1 \%$ dithiothreitol, bromophenol blue, $\mathrm{pH}$ 8.8) was added, and the samples were boiled for $5 \mathrm{~min}$ and separated on an SDS polyacrylamide gel. Proteins were electrotransferred for $60 \mathrm{~min}$ onto PVDF membranes (Immobilone; Millipore, Eschborn, Germany) using a semi-dry Western-blot technique. After blocking in $2 \%$ nonfat dried milk, the membranes were incubated overnight in appropriate dilutions of antibodies against pMet (Tyr 1234/5; \#3077), Met (\#3127), pAkt (Ser 473; \#4060), Akt (\#2920), pERK (Thr202/Tyr204) 1/2 (\#4370), pp70S6K (Thr389; \#9234), p70S6K (\#9202), p4EBP1 (Ser65; \#9451), 4EBP1 (\#9644), pGSK3 (Ser21/9; \#9331), GSK3 (\#9315), CDK4 (\#12790), CDK6 (\#13331), pChk1 (Ser345; \#2341), Chk1 (\#2360), cyclin B1 (\#12231), cyclin D1 (\#2978), cyclin D3 (\#2936), PARP (\#9542), PCNA (\#2586), E-cadherin (\#3195), N-cadherin (\#4061), $\beta$-catenin (\#8480), src (\#2109), vimentin (\#5741), ZO-1 (\#8193), all from Cell Signaling (Danvers, Mass., USA), twist (sc-15393; Santa Cruz, Dallas, Tex., USA), HGF (701283; Novex-Life, Frankfurt, Germany), actin (A5441; Sigma, St. Louis, Mo., USA), Erk 1/2 (06-182; Merck-Millipore, Darmstadt, Germany). After washing with TBS, the membranes were incubated with a peroxidase-conjugated secondary antibody (1: $25,000)$ for $2 \mathrm{~h}$. The blots were washed and immersed in the chemiluminescent substrate SuperSignal West Dura (Thermo Scientific, Rockford, Ill., USA), and images were taken with an ECL Chemocam Imager (INTAS, Göttingen, Germany).

\section{Statistical Analysis}

For proliferation assays, comparisons were evaluated using two-tailed Student's t test. Results are expressed as mean \pm SD of three or four independently performed experiments. Statistical significance was set at $\mathrm{p}<0.05$.

\section{Results}

\section{Human Neuroendocrine Tumor Cells Express}

Functional c-Met and Its Endogenous Ligand HGF

Western blot analysis demonstrated the expression of c-Met in human pancreatic neuroendocrine BON1, bronchopulmonary NCI-H727 and midgut GOT1 tumor cells, respectively (fig. 1a). Expression of the endogenous c-Met ligand HGF was found in BON1 and H727 tumor cells, but not in GOT1 cells (fig. 1b). Incubation of BON1, H727 and GOT1 cells with recombinant human HGF (rhHGF) at a concentration of $1.25 \mathrm{nM}$ for $10 \mathrm{~min}$ caused a significant induction of phospho-c-Met Y1234/5, while preincubation with the c-Met-inhibitor INC280 at a concentration of $100 \mathrm{nM}$ for $2 \mathrm{~h}$ completely abolished the baseline and HGF-stimulated phospho-c-Met Y1234/5 (fig. 1a). In addition, rhHGF stimulated phosphorylation 


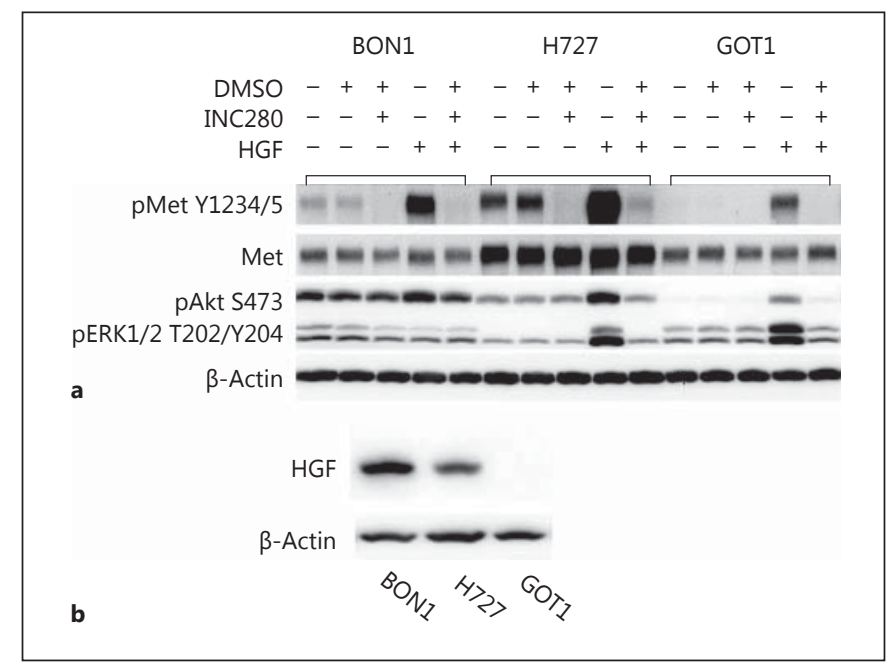

Fig. 1. a The endogenous c-Met ligand HGF induces c-MET phosphorylation in neuroendocrine tumor cells, which is blocked by the specific c-Met inhibitor INC280. Human pancreatic neuroendocrine BON1, bronchopulmonary H727 and midgut GOT1 cells were incubated with HGF (1.25 nM) for $10 \mathrm{~min}$. A preincubation with INC280 (100 $\mathrm{nM})$ for $2 \mathrm{~h}$ was performed in the control group and the HGF treatment group. Subsequently, the expression of phospho-c-Met Y1234/5, c-Met, pAkt S473, pERK1/2 T202/Y204 and $\beta$-actin loading control was evaluated by Western blot analysis. A representative blot out of three independently performed experiments is shown. b Endogenous HGF expression by neuroendocrine tumor cells. Cell lysates of untreated BON1, NCI-H727 and GOT1 neuroendocrine tumor cells were harvested. Subsequently, the expression of HGF and $\beta$-actin loading control was evaluated by Western blot analysis. A representative blot out of three independently performed experiments is shown.

of Akt and ERK1/2, while preincubation with the c-Metinhibitor INC280 at a concentration of $100 \mathrm{nM}$ for $2 \mathrm{~h}$ prevented any stimulation (fig. 1a).

Thus, these data demonstrate the expression of a functional c-Met receptor on all three human neuroendocrine tumor cell lines investigated. However, the expression of the endogenous c-Met ligand HGF and expression of activated c-Met (phospho-c-Met Y1234/5) in untreated cells were only found in BON1 and H727 cells, while it could not be detected in GOT1 cells.

Cabozantinib and Tivantinib Inhibit Cell Viability of Neuroendocrine Tumor Cells, while the Specific c-Met Inhibitor INC280 Has No Effect

Human pancreatic neuroendocrine BON1, bronchopulmonary NCI-H727 and midgut GOT1 tumor cells were incubated with INC280, cabozantinib and tivantinib at a concentration range of $1 \mathrm{nM}$ to $10 \mu \mathrm{M}$, for $24 \mathrm{~h}$ (fig. $2 \mathrm{a}$ ),
48 h (fig. 2b) and 72 h (fig. 2c), respectively. Cabozantinib and tivantinib at lower concentrations of 1 and $100 \mathrm{nM}$ demonstrated no constant significant effects on cell viability of the three tumor cell lines. However, cabozantinib $10 \mu \mathrm{M}$ caused a significant decrease in cell viability in BON1, H727 and GOT1 cells, each at 24, 48 and $72 \mathrm{~h}$, respectively (fig. 2). At $72 \mathrm{~h}$, cabozantinib $10 \mu \mathrm{M}$ caused a decrease in cell viability in BON1 cells to $51.1 \pm 2.3 \%$ ( $\mathrm{p}<0.001), \mathrm{H} 727$ cells to $59.3 \pm 2.1 \%(\mathrm{p}<0.001)$ and GOT1 cells to $30.5 \pm 9.3 \%(\mathrm{p}<0.01)$, respectively. Also tivantinib $10 \mu \mathrm{M}$ caused a significant decrease in cell viability in BON1 and H727 cells at 24, 48 and $72 \mathrm{~h}$, respectively (fig. 2), but had no effect on cell viability of GOT1 cells (fig. 2). At $72 \mathrm{~h}$, tivantinib $10 \mu \mathrm{M}$ caused a decrease in cell viability in BON1 cells to $28.1 \pm 5.2 \%(\mathrm{p}<0.001)$ and in H727 cells to $65.9 \pm 7.4 \%$ ( $p<0.01)$. In contrast, no significant effect of tivantinib $10 \mu \mathrm{M}$ was observed on cell viability of GOT1 cells [98.8 $\pm 13.9 \%$ (n.s.)]. In contrast, INC280 at all tested concentrations of 1 and $100 \mathrm{nM}$, and $10 \mu \mathrm{M}$ demonstrated no constant significant effects on cell viability of the three tumor cell lines (fig. 2). At $72 \mathrm{~h}$, INC280 $10 \mu \mathrm{M}$ caused only minimal changes in cell viability in BON1 cells to $105.3 \pm 2.9 \%(\mathrm{p}<0.05)$, in $\mathrm{H} 727$ cells to $91.0 \pm 4.5 \%(\mathrm{p}<0.05)$ and in GOT1 cells to $99.1 \pm$ $3.9 \%$ (n.s.), respectively.

Thus, these data demonstrate that cabozantinib and tivantinib at a concentration of $10 \mu \mathrm{M}$ potently inhibit cell viability in human neuroendocrine tumor cell lines, while INC280 does not. The antiproliferative effects of INC280, cabozantinib and tivantinib (fig. 2) are not correlated and not congruent with their efficacy as a c-Met inhibitor (see fig. 4a), as demonstrated below. The antiproliferative efficacies of cabozantinib on BON1, H727 and GOT1 cells (fig. 2) do not correlate with the respective expression levels of activated c-Met (phospho-c-Met Y1234/5) in these cell lines (fig. 1a).

Inhibition of c-Met Expression by c-Met siRNA Does Not Inhibit Cell Viability of Neuroendocrine Tumor Cells

Human pancreatic neuroendocrine BON1 and bronchopulmonary NCI-H727 cells were transfected with nontargeted $\beta$-gal siRNA ( $50 \mathrm{nM}$ ) or siRNA against c-Met (50 nM). The effectiveness of the siRNAs was verified by Western blot analysis $72 \mathrm{~h}$ after transfection, and siRNA against c-Met demonstrated a significant decrease in cMet expression (fig. 3a). Cell viability $72 \mathrm{~h}$ after transfection with nontargeted $\beta$-gal siRNA versus c-Met siRNA (fig. 3b) was not significantly affected in BON1 cells (45.8 $\pm 25.7 \%$ vs. $46.6 \pm 25.2 \%$; n.s.), and only a minimal effect 

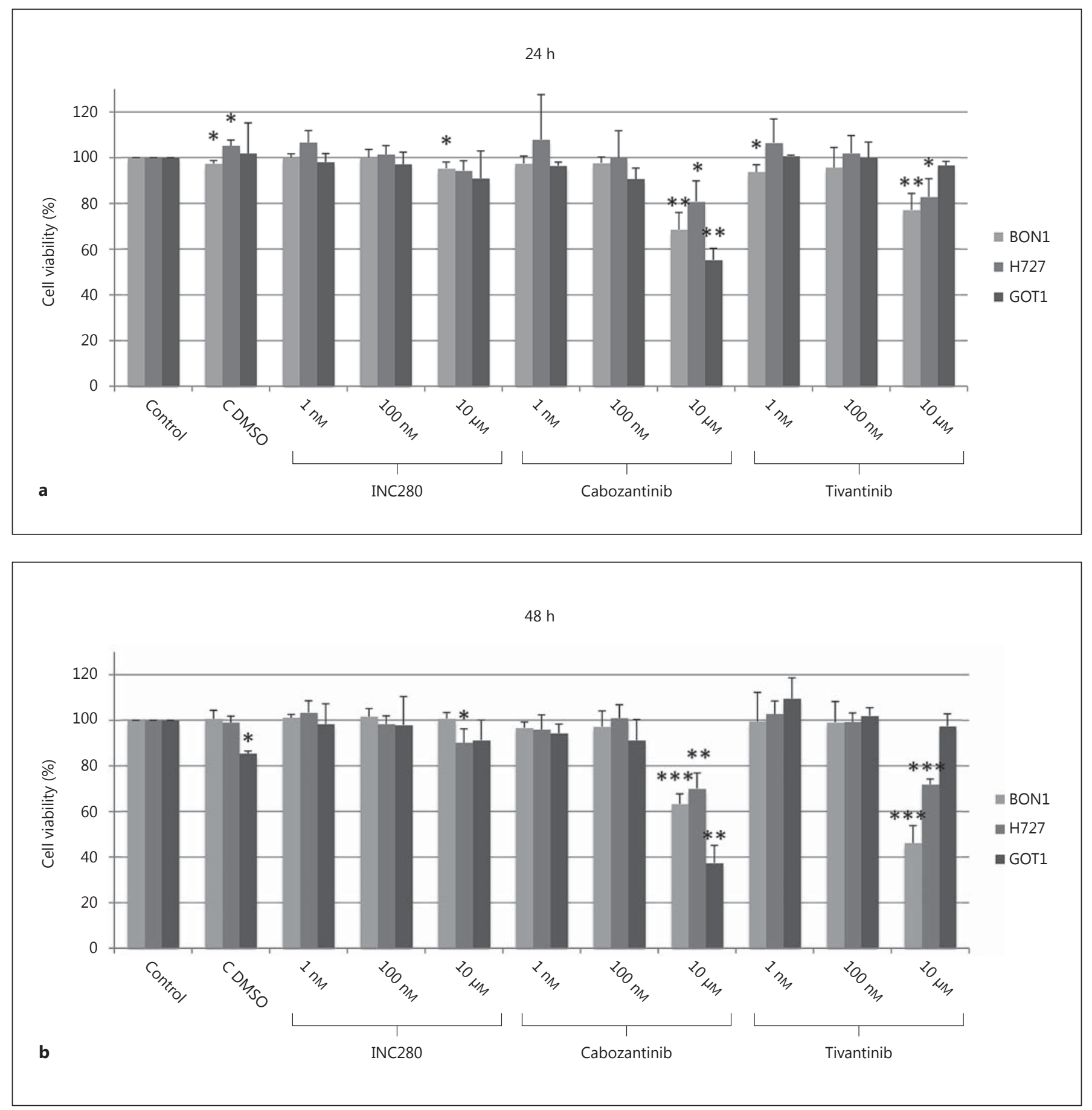

Fig. 2. Differential effects of INC280, cabozantinib and tivantinib on cell viability of neuroendocrine tumor cells. Human pancreatic neuroendocrine BON1, bronchopulmonary NCI-H727 and midgut GOT1 cells were incubated with INC280, cabozantinib and tivantinib at a concentration range of $1 \mathrm{nM}$ to $10 \mu \mathrm{M}$ for $24 \mathrm{~h}(\mathbf{a}), 48 \mathrm{~h}(\mathbf{b})$ and $72 \mathrm{~h}(\mathbf{c})$, respectively. Cell viability was measured with Cell Titer 96 kit (Promega). The arithmetic means and standard deviation of four independent experiments are shown. Statistical analysis with $\mathrm{t}$ test showed significant results for $1 \mathrm{nM}$ to $10 \mu \mathrm{M}$ with ${ }^{*} \mathrm{p}<0.05,{ }^{* *} \mathrm{p}<0.01$ and ${ }^{* * *} \mathrm{p}<0.001$.

(For figure $2 c$ see next page.) 


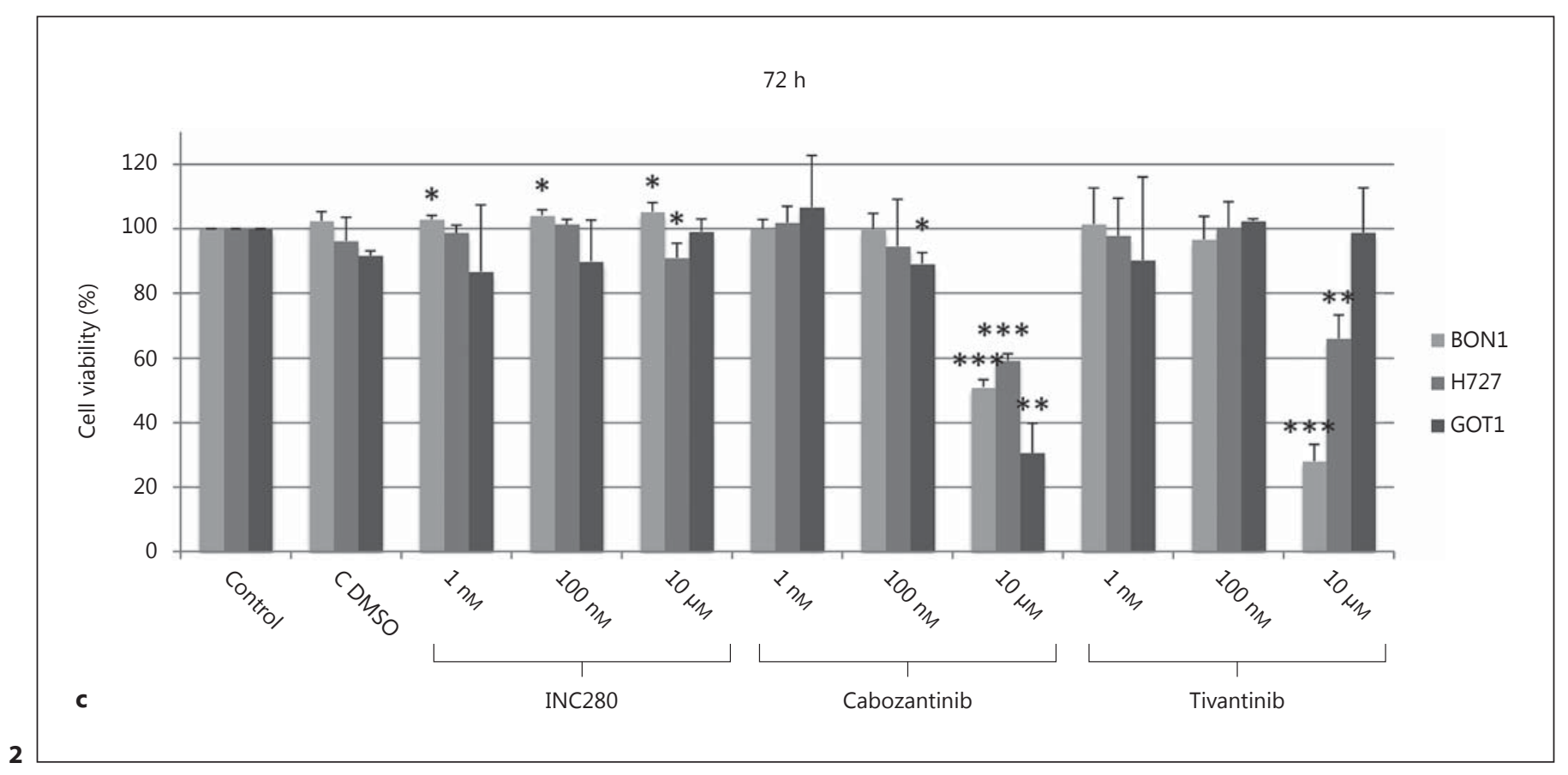

was seen in H727 cells ( $94.7 \pm 8.9 \%$ vs. $89.5 \pm 3.2 \%$; $\mathrm{p}<$ $0.05)$, respectively.

Thus, these data demonstrate that inhibition of c-Met expression does not affect or only minimally affects cell viability of neuroendocrine tumor cells.

\section{Differential Effects of INC280, Cabozantinib and \\ Tivantinib on c-Met Activity and EGFR, Akt and MAPK Signaling}

Human pancreatic BON1 and bronchopulmonary NCI-H727 cells were incubated with INC280, cabozantinib and tivantinib, respectively, in concentrations of 1 , 100 and 10,000 $\mathrm{nm}$ for $24 \mathrm{~h}$, followed by protein extraction and Western blot analysis (fig. 4a). Expression of activated phospho-c-Met Y1234/5 was already partially inhibited by INC280 and cabozantinib at the lowest concentration of $1 \mathrm{nM}$, while concentrations of 100 and 10,000 nM completely abolished phospho-c-Met Y1234/5 expression, respectively (fig. 4a). In contrast, tivantinib demonstrated a partial inhibition of phospho-c-Met Y1234/5 expression in BON1 cells only at the highest concentration of 10,000 nM (fig. 4a). Thus, these data demonstrate that the c-Met-inhibitor efficacy of INC280 and cabozantinib in neuroendocrine tumor cells is in a similar low nanomolar range, while tivantinib, even at the highest concentration tested, caused only a partial inhibition of activated phospho-c-Met Y1234/5 expression (fig. 4a).
The c-Met-inhibitor efficacy of either drug and the extent of inhibition of activated phospho-c-Met Y1234/5 expression during drug incubation (fig. 4a) do not correlate with the respective antiproliferative efficacies of INC280, cabozantinib and tivantinib on BON1 and H727 cells (fig. 2).

As Akt/mTOR signaling and MAPK signaling is essentially involved in neuroendocrine tumor cell proliferation [28-30], an analysis of various markers of Akt/mTOR signaling and MAPK signaling was performed (fig. 4b, c). Human pancreatic BON1 and bronchopulmonary NCIH727 cells were incubated with INC280 (10,000 nM), cabozantinib (10,000 $\mathrm{nM})$ and tivantinib $(10,000 \mathrm{nM})$ for $2,24,48$ and $72 \mathrm{~h}$, respectively, followed by protein extraction and Western blot analysis (fig. 4b, c). Cabozantinib and tivantinib caused late-onset effects at 48 and $72 \mathrm{~h}$ with a decrease in phospho-EGFR in BON1 and NCI-H727 cells (fig. 4b, c). Cabozantinib also demonstrated an early negative effect on phospho-IGF-1R at $2 \mathrm{~h}$ in BON1 and NCI-H727 cells (fig. 4b, c). Cabozantinib and tivantinib caused inhibition of pAkt and p4EBP1S65 in BON1 cells at $72 \mathrm{~h}$ (fig. 4b), but not in H727 cells (fig. 4c). INC280 and cabozantinib caused induction of GSK3 phosphorylation at pGSK3 S21/9 in BON1 cells at $72 \mathrm{~h}$ (fig. 4b), while cabozantinib and tivantinib caused induction of pGSK3 S21/9 in H727 cells at $72 \mathrm{~h}$ (fig. 4c). A modest compensatory activation of phospho-Erk1/2 

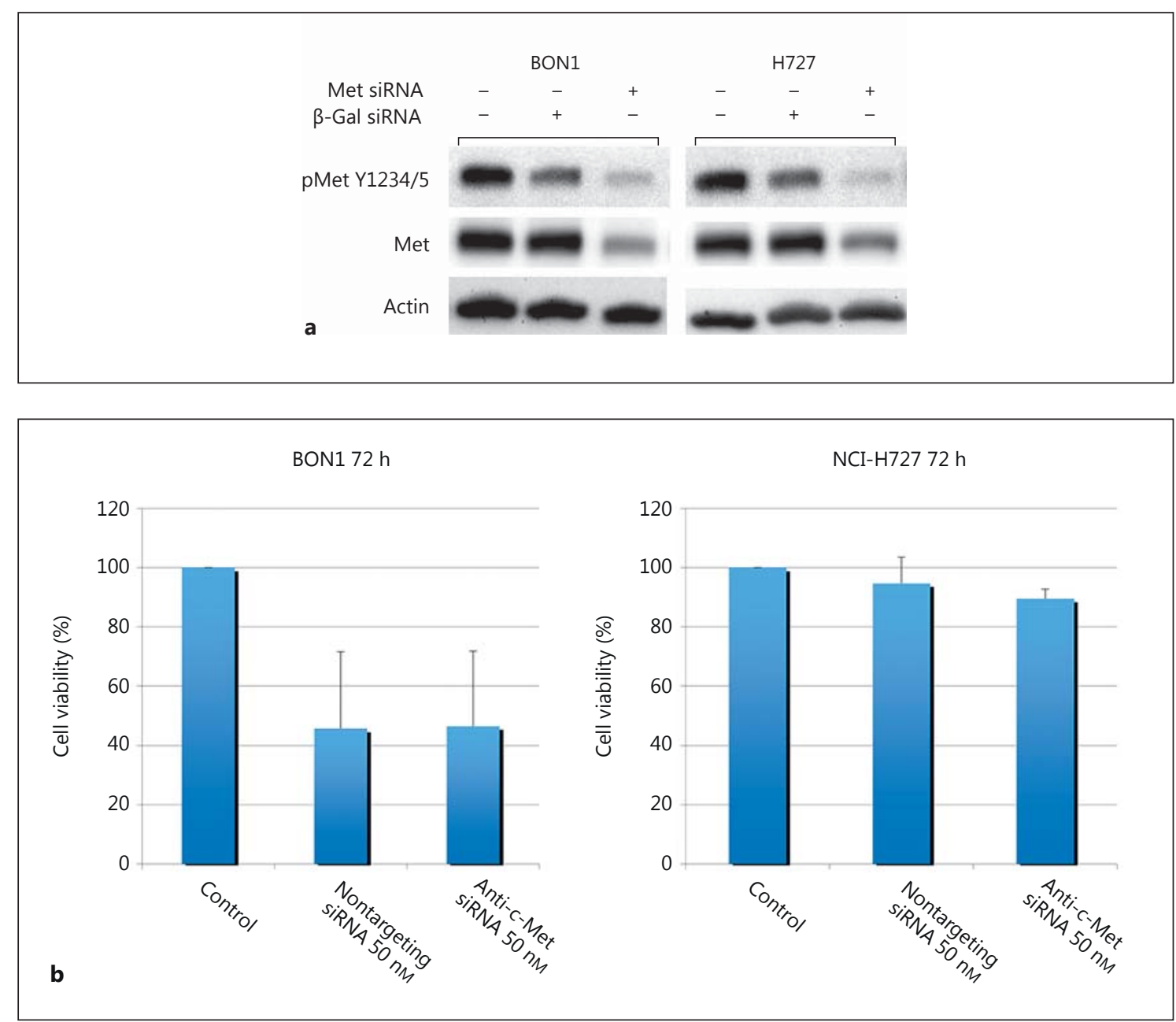

Fig. 3. Effects of c-Met siRNA on c-Met expression and cell viability of neuroendocrine tumor cells. Human pancreatic neuroendocrine BON1 and bronchopulmonary NCI-H727 cells were transfected with nontargeted $\beta$-gal siRNA $(50 \mathrm{nM})$ or siRNA against c-Met $(50 \mathrm{nM})$. The effectiveness of the siRNAs was verified by Western blot analysis of c-Met expression $72 \mathrm{~h}$ after transfection. a One representative blot out of three performed experiments is shown. b Cell viability in siRNA-treated BON1 and NCI-H727 cells was measured with Cell Titer 96 kit (Promega) $72 \mathrm{~h}$ after transfection. The mean values \pm SD of three independently performed experiments are shown.

T202/Y204 by INC280, cabozantinib and tivantinib could be detected at $2 \mathrm{~h}$ in BON1 cells (fig. $4 \mathrm{~b}$ ) and by cabozantinib and tivantinib at $24 \mathrm{~h}$ in $\mathrm{H} 727$ cells (fig. 4c). In contrast, none of the above described effects were observed in a similar manner with INC280 (fig. 4b, c).

\section{Cabozantinib and Tivantinib Cause a G2 Arrest of}

Neuroendocrine Tumor Cells, while the Specific c-Met

Inhibitor INC280 Has No Effect

Human pancreatic neuroendocrine BON1 (fig. 5a, b) and bronchopulmonary NCI-H727 (fig. 5c, d) cells were incubated with equimolar concentrations $(10,000 \mathrm{nM})$ of
INC280, cabozantinib and tivantinib for $24 \mathrm{~h}$, followed by FACS analysis. In BON1 cells, cabozantinib and tivantinib caused a significant accumulation in G2 phase with $54.9 \pm 13.9 \%(\mathrm{p}<0.05)$ and $75.6 \pm 7.9 \%(\mathrm{p}<0.01)$ versus $17.5 \pm 3.2 \%$ G2 phase in the control group (fig. $5 b$ ). In H727 cells, cabozantinib and tivantinib caused a significant accumulation in G2 phase with $31.9 \pm 4.4 \%$ (n.s., $\mathrm{p}=0.2)$ and $53.7 \pm 4.7 \%(\mathrm{p}<0.05)$ versus $26.6 \pm 6.4 \% \mathrm{G} 2$ phase in the control group (fig. 5d). In contrast, INC280 did not exert a significant effect on the percentage of cells in the $\mathrm{G} 2$ phase neither in BON1 cells with $17.0 \pm 5.3 \%$ (n.s.) versus $17.5 \pm 3.2 \%$ G2 phase in the control group 

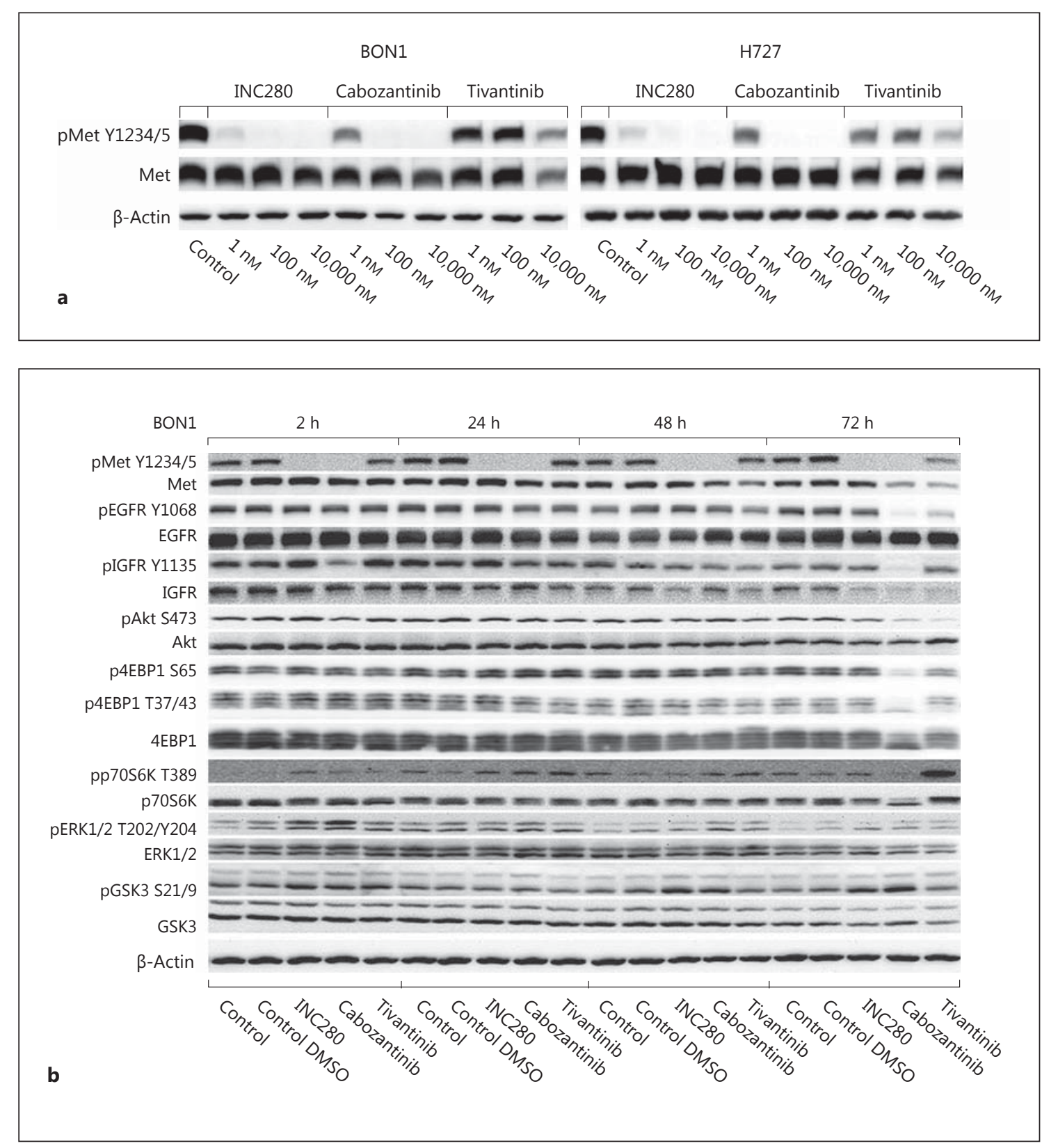

Fig. 4. Differential effects of INC280, cabozantinib and tivantinib on c-Met activity and EGFR, Akt and MAPK signaling. a Human pancreatic neuroendocrine BON1 and bronchopulmonary NCIH727 cells were incubated with INC280, cabozantinib and tivantinib, respectively, in increasing concentrations of $1-10,000 \mathrm{nM}$ for $24 \mathrm{~h}$. Subsequently, the expression of phospho-c-Met Y1234/5, cMet and $\beta$-actin loading control was evaluated by Western blot analysis. One representative blot out of three independently performed experiments is shown. Human pancreatic neuroendocrine
BON1 (b) and bronchopulmonary NCI-H727 (c) cells were incubated with INC280 (10,000 nM), cabozantinib (10,000 nM) and tivantinib (10,000 nM) for 2, 24, 48 and $72 \mathrm{~h}$, respectively. Subsequently, the expression of phospho-c-Met Y1234/5, c-Met, pEGFR Y1068, EGFR, pIGFR Y1135, IGFR, pAkt S473, Akt, p4EBP1 S65, p4EBP1 T37/47, 4EBP1, pp70S6K T389, pERK1/2 T202/Y204, ERK1/2, pGSK3 S21/9, GSK3 and $\beta$-actin loading control was evaluated by Western blot analysis. One representative blot out of three independently performed experiments is shown.

(For figure $4 c$ see next page.) 


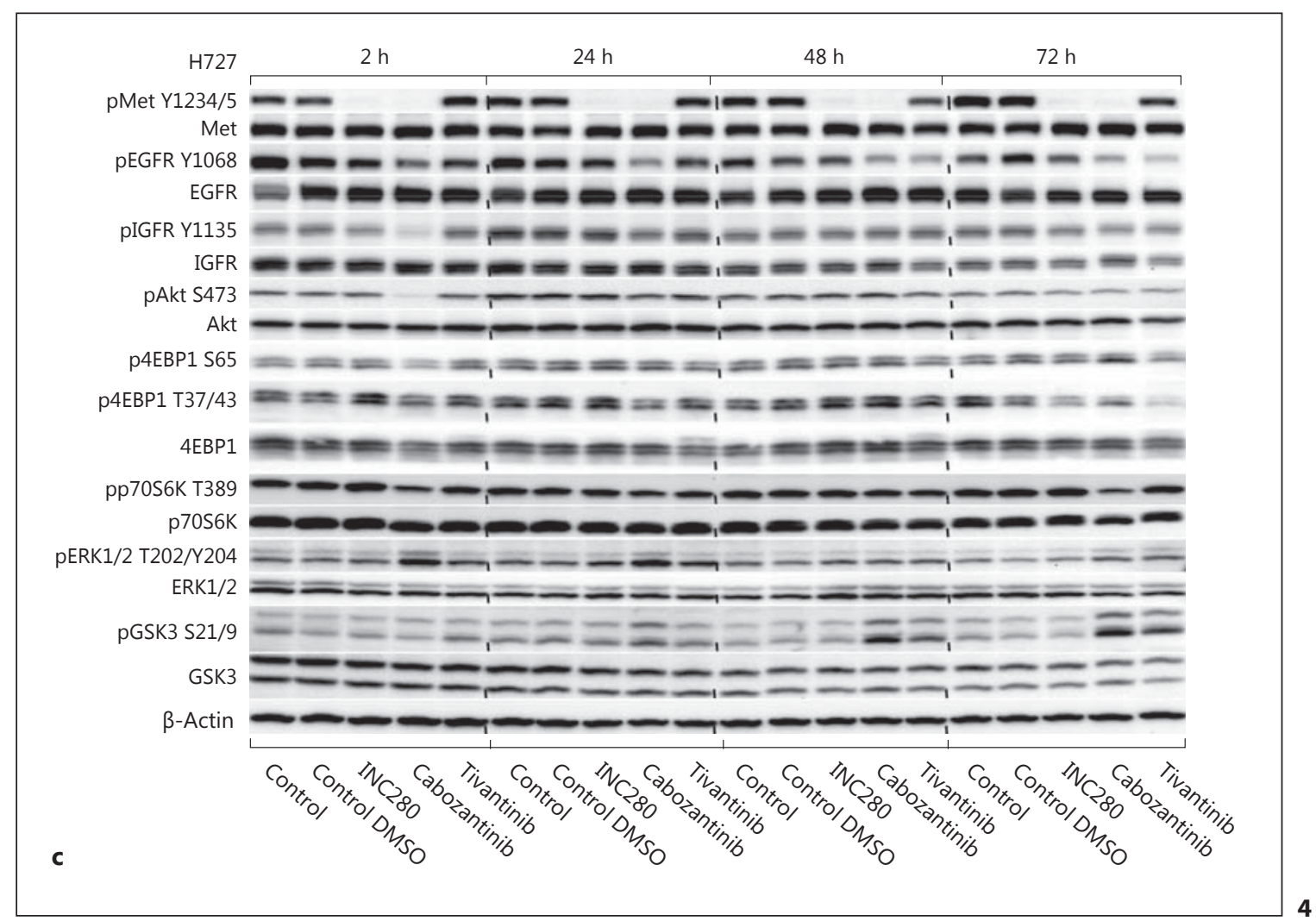

(fig. 5b), nor in H727 cells with $27.1 \pm 6.1 \%$ (n.s.) versus $26.6 \pm 6.4 \%$ G2 phase in the control group (fig. $5 \mathrm{~d}$ ).

\section{Differential Effects of INC280, Cabozantinib and}

Tivantinib on c-Met Activity and Various Parameters of Cell Cycle Regulation and Apoptosis

Human pancreatic BON1 and bronchopulmonary NCI-H727 cells were incubated with INC280 $(10,000$ $\mathrm{nM})$, cabozantinib $(10,000 \mathrm{nM})$ and tivantinib $(10,000$ $\mathrm{nM}$ ) for $2,24,48$ and $72 \mathrm{~h}$, respectively, followed by protein extraction and Western blot analysis (fig. 6a, b).

Cabozantinib and tivantinib demonstrated late-onset effects at $72 \mathrm{~h}$ with inhibition of the expression of cyclin D1 and proliferation marker PCNA in BON1 cells (fig. 6a) and $\mathrm{H} 727$ cells (fig. 6b). Tivantinib upregulated cyclin B1 expression at $24 \mathrm{~h}$ in BON1 cells (fig. 6a) and H727 cells (fig. 6b). While these findings indicate that cabozantinib and tivantinib affect cell cycle regulation, cabozantinib or tivantinib had no effect on cleavage of the apoptosis marker PARP (fig. 6a, b).

Cabozantinib and tivantinib cause a G2 arrest in BON1 and H727 cells (fig. 5). Therefore, we also investigated protein expression of the G2 checkpoint regulator Chk1.
The effects of cabozantinib or tivantinib on pChk1S345/ Chk1 expression were different in BON1 and H727 cells (fig. 6a, b), indicating a cell type-specific regulation.

Cabozantinib and Tivantinib Inhibit Cell Migration of Neuroendocrine Tumor Cells, while the Specific c-Met Inhibitor INC280 Has No Effect

Human pancreatic neuroendocrine BON1 (fig. 7a, b) and bronchopulmonary NCI-H727 (fig. 7c, d) cells were incubated with INC280, cabozantinib and tivantinib, respectively, at a concentration of $100 \mathrm{nM}$ and $10 \mu \mathrm{M}$ for $72 \mathrm{~h}$. The gap width at 0 and $72 \mathrm{~h}$, respectively, for each treatment group was analyzed (fig. $7 \mathrm{~b}, \mathrm{~d}$ ). In BON1 cells, cabozantinib and tivantinib at the highest concentration of 10,000 nM inhibited cell migration into the gap and restored the gap width with $84.7 \pm 3.4 \%(\mathrm{p}<0.05)$ and 82.9 $\pm 17.9 \%$ (n.s., $p=0.1$ ), respectively (fig. $7 b$ ). In contrast, INC280 had no significant inhibitory effect on cell migration into the gap and did not restore the gap width in comparison to control with $9.3 \pm 11.3 \%$ (n.s., $\mathrm{p}=0.1$ ) versus $29.2 \pm 19.2 \%$ (fig. 7b). In H727 cells, cabozantinib and tivantinib inhibited cell migration into the gap and restored the gap width with $102.5 \pm 20.6 \%(\mathrm{p}<0.05)$ and 

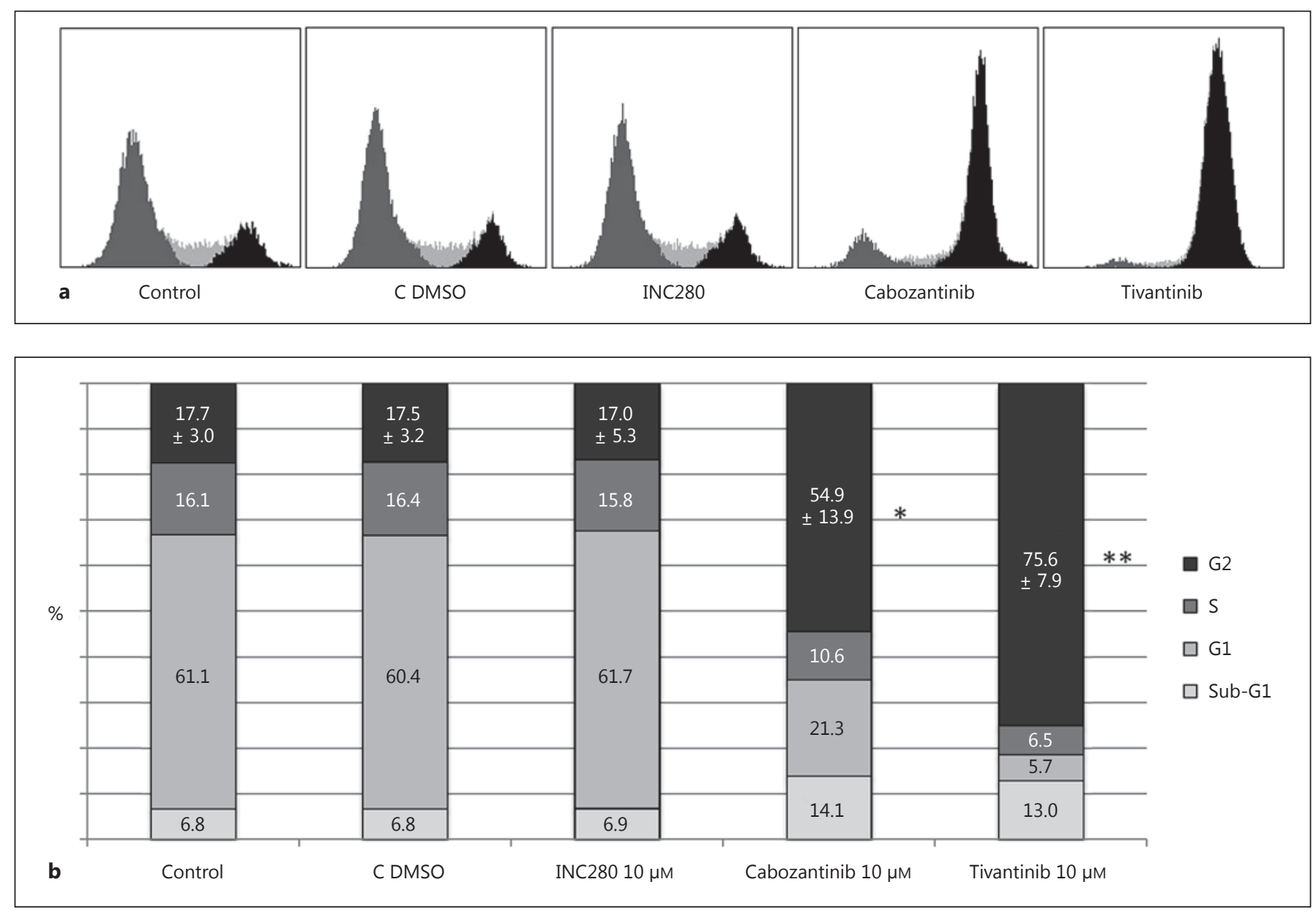

Fig. 5. Differential effects of INC280, cabozantinib and tivantinib on G2 arrest of neuroendocrine tumor cells. Human pancreatic neuroendocrine BON1 (a, b) and bronchopulmonary NCI-H727 (c, d) cells were incubated with INC280, cabozantinib and tivantinib, respectively, at a concentration of $10,000 \mathrm{nM}$ for $24 \mathrm{~h}$. FACS analysis analyzed G2, S, G1 and sub-G1 events, respectively. a, c A

$66.1 \pm 2.2 \%(\mathrm{p}<0.05)$, respectively (fig. $7 \mathrm{~d})$. In contrast, INC280 had no significant inhibitory effect on cell migration into the gap and did not restore the gap width in comparison to control with $33.7 \pm 16.8 \%$ (n.s., $\mathrm{p}=0.5$ ) versus $38.9 \pm 7.0 \%$ (fig. $7 \mathrm{~d}$ ).

Thus, these data demonstrate that cabozantinib and tivantinib at a concentration of $10 \mu \mathrm{M}$ inhibit cell migration in human neuroendocrine tumor cell lines, while INC280 does not. The antimigratory effects of INC280, cabozantinib and tivantinib (fig. 7) are not correlated and not congruent with their efficacy as a c-Met inhibitor (fig. 4), as demonstrated before.

Next, we evaluated whether the antimigratory effects of cabozantinib and tivantinib are mediated by epithelial representative FACS analysis out of three independently performed experiments is shown. $\mathbf{b}, \mathbf{d}$ The mean values \pm SD of three independently performed experiments are shown. Statistical analysis with $\mathrm{t}$ test showed significant results with ${ }^{*} \mathrm{p}<0.05,{ }^{* *} \mathrm{p}<0.01$ and ${ }^{* * *} \mathrm{p}<0.001$.

(For figures $5 c$ and $d$ see next page.)

mesenchymal transition (EMT) markers. However, no effects were detected in Western blot analysis of a panel of appropriate EMT markers (fig. 8).

\section{Discussion}

The HGF/HGF receptor c-Met axis has been defined as a potential target in cancer therapy of various tumor entities [7-10]. In this study, we aimed to investigate whether single c-Met inhibition is sufficient to inhibit neuroendocrine tumor cell growth and migration in vitro, and to further characterize the role of the HGF/c-Met axis in neuroendocrine tumors. The effects of the multi- 

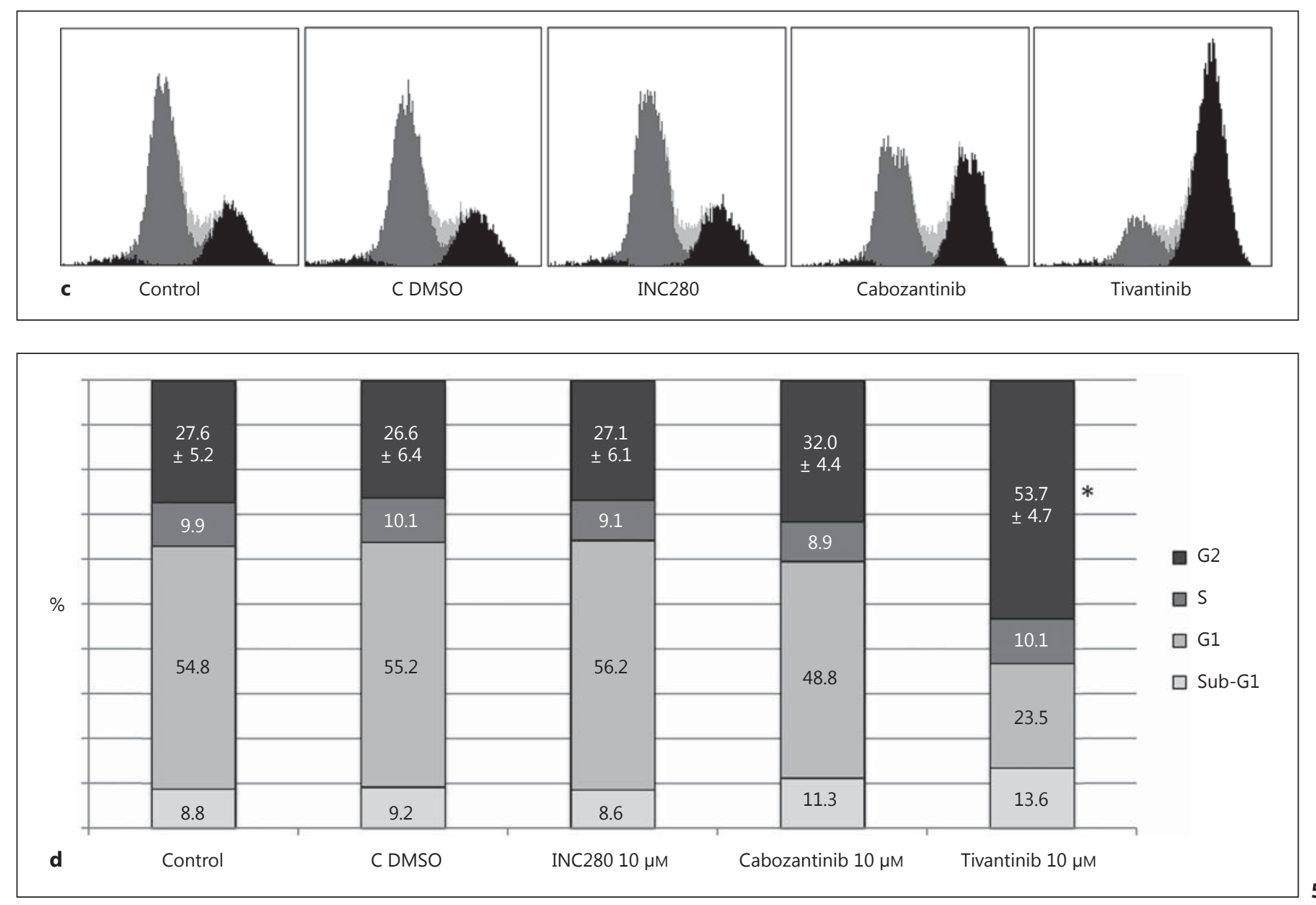

TKIs cabozantinib and tivantinib and of the highly specific c-Met inhibitor INC280 were investigated in human pancreatic neuroendocrine BON1, bronchopulmonary NCI-H727 and midgut GOT1 cells in vitro.

All three human neuroendocrine tumor cell lines BON1 (pancreatic NET), NCI-H727 (bronchopulmonary carcinoid) and GOT1 (midgut carcinoid) expressed c-Met (fig. 1a). The functionality of c-Met was proven by rhHGF-induced stimulation of phospho-c-Met in all three cell lines. HGF stimulation also induced downstream Akt and ERK signaling. HGF-induced phosphorylation of c-Met and its downstream signals Akt and Erk were inhibited by the specific c-Met inhibitor INC280.

Expression of c-Met has been reported as a putative target in neuroendocrine tumors $[31,32]$. In 39 pancreatic neuroendocrine neoplasms, protein expression analysis revealed c-Met overexpression in 17\% (4/24) of nonmetastasized NET, 33\% (5/15) of metastasized NET, 57\% (4/7) of lymph node metastases and 56\% (5/9) of liver

Effect of c-Met Inhibition on Human NET Cells metastases, respectively [33]. In human pancreatic neuroendocrine $\mathrm{BON} 1$ cells, microarray analysis using a small array of 2,503 genes revealed 101 HGF-responsive genes, including genes with a putative function in oncogenesis, cell proliferation, apoptosis or cell adhesion/motility [34]. In 10 gastrinomas, protein expression of HGF receptor c-Met was detectable in $90 \%$, while competitive PCR in 38 gastrinomas revealed c-Met overexpression in $14 \%$ compared to normal pancreas [35]. Overexpression of c-Met was a negative prognostic indicator in gastrinomas [35]. In 17 ileal NETs and 28 nonileal NETs, high staining of c-Met immunoreactivity was found in $100 \%$ of ileal NETs and 32\% of nonileal NETs [36]. The human midgut carcinoid cell line CNDT2 expresses c-Met [37]. In bronchopulmonary neuroendocrine neoplasms, strong c-Met expression was observed in 66\% (25/38) of typical carcinoids, $67 \%$ (4/6) of atypical carcinoids, 50\% (17/34) of SCLC and 55\% (6/11) of LCNEC [38]. A strong expression of activated phospho-c-Met was observed in 


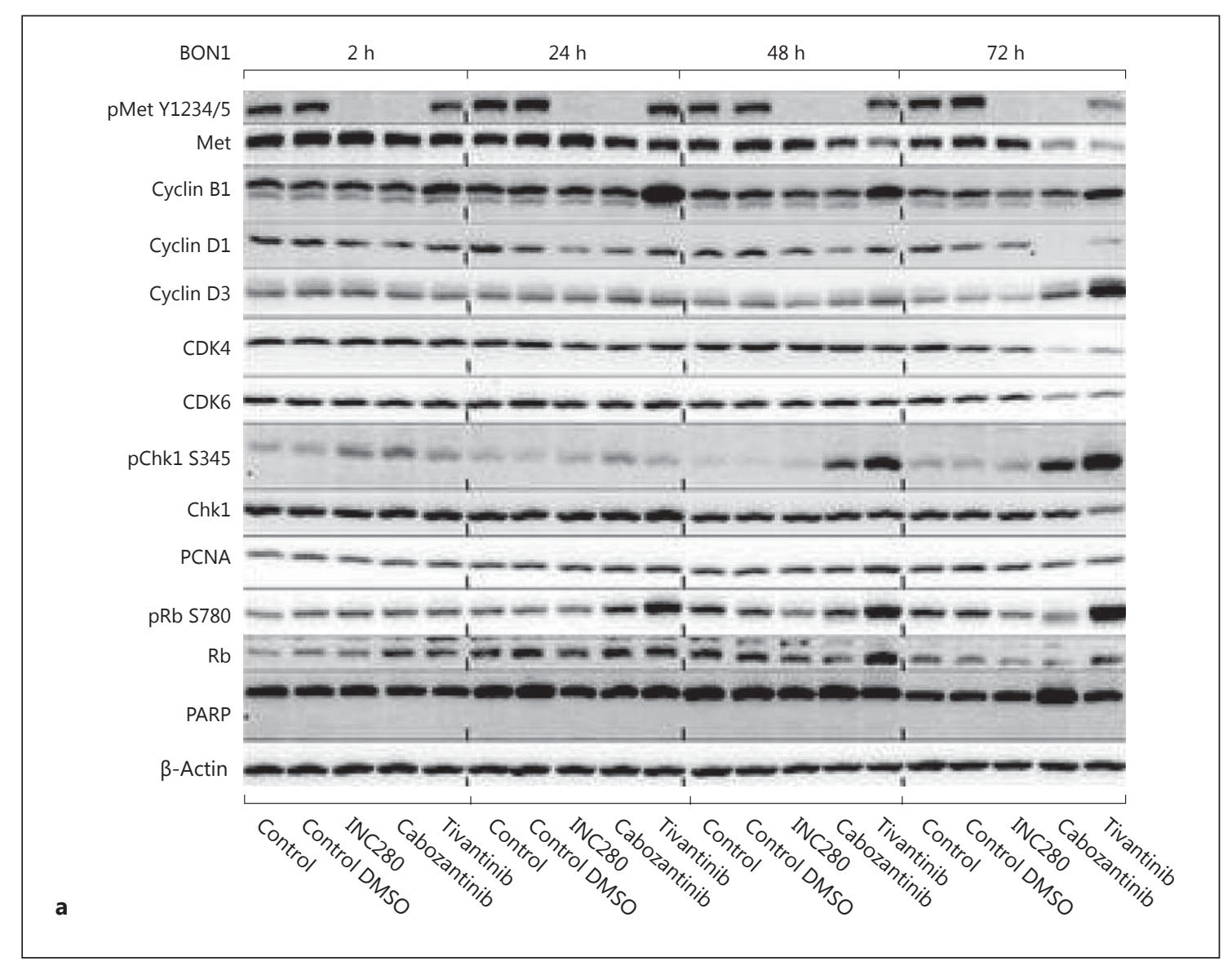

Fig. 6. Differential effects of INC280, cabozantinib and tivantinib on c-Met activity and various parameters of cell cycle regulation and apoptosis. Human pancreatic neuroendocrine BON1 (a) and bronchopulmonary NCIH727 (b) cells were incubated with INC280 (10,000 nM), cabozantinib (10,000 nM) and tivantinib (10,000 nM) for 2, 24, 48 and $72 \mathrm{~h}$, respectively. Subsequently, the expression of phospho-c-Met Y1234/5, c-Met, cyclin B1, cyclin D1, cyclin D3, CDK4, CDK6, pChk1 S345, Chk1, PCNA, pRb S780, Rb, PARP and $\beta$-actin loading control was evaluated by Western blot analysis. One representative blot out of three independently performed experiments is shown.

(For figure $6 b$ see next page.)

$50 \%(19 / 38)$ of typical carcinoids, $67 \%(4 / 6)$ of atypical carcinoids, $68 \%(23 / 34)$ of SCLC and $36 \%(4 / 11)$ of LCNEC [38]. C-Met mutations have been reported to be relatively rare in bronchopulmonary neoplasias with $6.5 \%$ in 46 SCLC and $8.3 \%$ in 36 NETs [39]. These mutations were not functionally relevant in regard of c-Met phosphorylation status [39]. Serum levels of HGF were significantly higher in patients with bronchopulmonary carcinoid tumors than in healthy controls [40].

INC 280, cabozantinib and tivantinib inhibited c-Met phosphorylation in neuroendocrine tumor cells (fig. 4). Comparing equimolar concentrations, INC280 was the most potent c-Met inhibitor compared to cabozantinib and tivantinib (fig. 4a). This finding is in accordance with the literature. For the ATP-competitive c-Met inhibitor INC280 (synonyms: INCB28060, capmatinib) an IC50 of $0.13 \mathrm{nM}$ towards c-Met in a kinase assay and an IC50 for c-Met phosphorylation in cells in vitro of $0.3-1.1 \mathrm{nM}$ have been reported [41]. For the ATP-competitive c-Met inhibitor cabozantinib (synonym: XL184), an IC50 of 1.3 $\mathrm{nM}$ towards c-Met in a kinase assay has been demonstrated [42]. The non-ATP-competitive c-Met inhibitor tivantinib (synonym: ARQ197) has been demonstrated as a calculated inhibitory constant $\mathrm{Ki}$ of $355 \mathrm{nM}$ towards cMet in a kinase assay and an IC50 for c-Met phosphorylation in cells in vitro of 100-300 nM [43]. Thus, according to the literature [41-43], INC280 inhibits c-Met phosphorylation in vitro with an approximately 10 -fold high- 


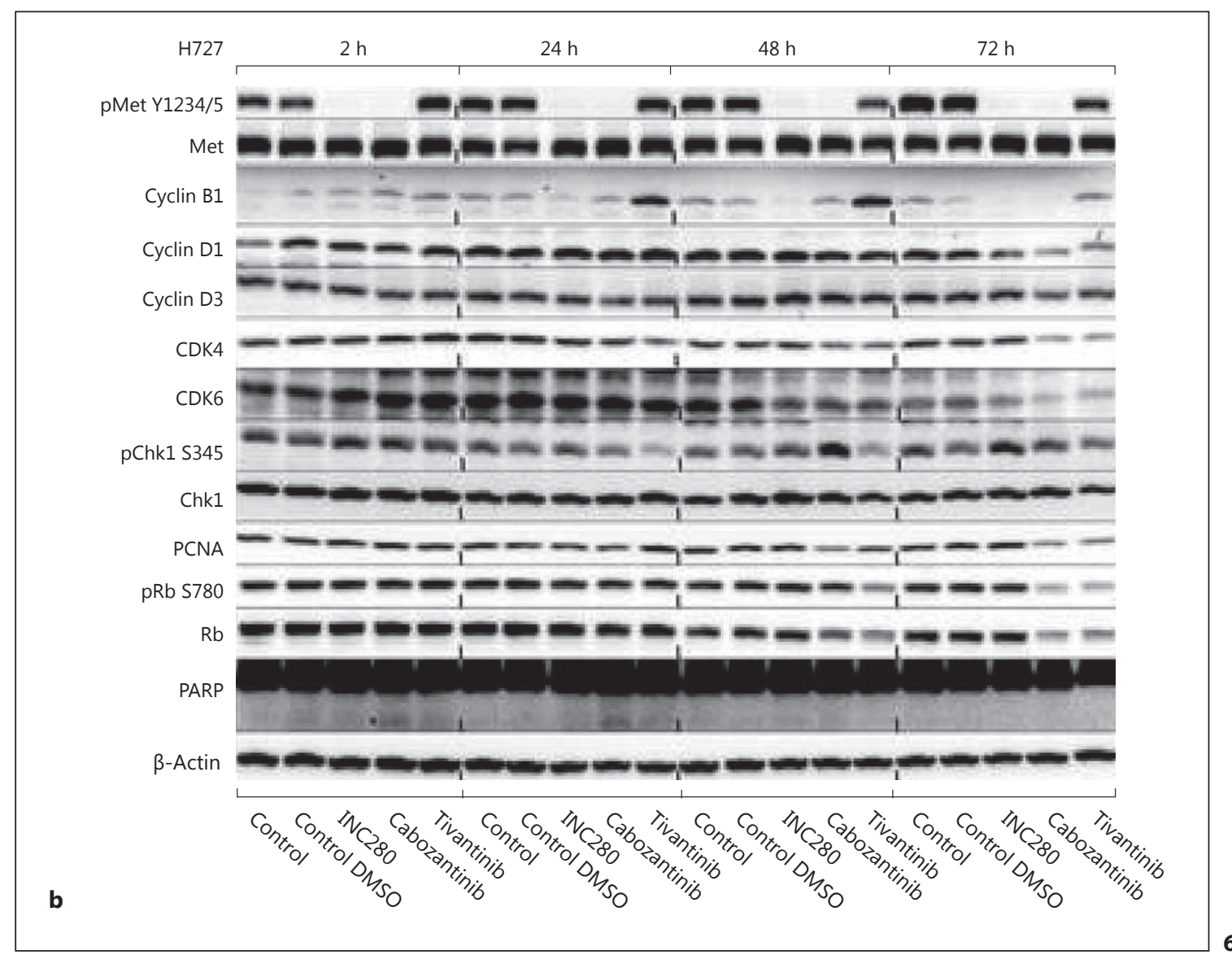

er efficacy compared to cabozantinib and with an approximately 100- to 1,000-fold higher efficacy compared to tivantinib. This different potency in inhibition of c-Met phosphorylation was also found in our experiments comparing INC280, cabozantinib and tivantinib (fig. 4a). Similar to our data, also in epithelioid sarcoma cell lines has the highly selective c-Met inhibitor INC280 been reported to inhibit phospho-c-Met at concentrations of $1 \mathrm{nM}[44]$.

Although in our study equimolar concentrations (10 $\mu \mathrm{M}$ ) of cabozantinib and tivantinib potently inhibited cell viability (fig. 2) and cell migration (fig. 7), the highly specific c-Met inhibitor INC280 had no effect on cell viability (fig. 2) or cell migration (fig. 7). Similarly, equimolar concentrations $(10 \mu \mathrm{M})$ of cabozantinib and tivantinib caused a potent $\mathrm{G} 2$ arrest in neuroendocrine tumor cells, while INC 280 had no effect (fig. 5). Knockdown experiments with c-Met siRNA also demonstrated no effect or only minor effects on neuroendocrine tumor cell viability (fig. 3). Our in vitro data suggest that c-Met inhibition

Effect of c-Met Inhibition on Human NET Cells alone is not sufficient to exert direct antitumoral or antimigratory effects in neuroendocrine tumor cells in vitro. In contrast, the multi-TKIs cabozantinib and tivantinib show promising antitumoral and antimigratory effects in neuroendocrine tumor cells, which are most probably 'off-target' effects, not mediated by c-Met.

In the Rip-Tag2 mouse model of pancreatic neuroendocrine tumors, the multi-TKI cabozantinib (with activity against c-Met, VEGFR2, c-KIT, FLT3, RET and TIE2) has been demonstrated to be superior in comparison to compounds with anti-VEGF activity only in inhibition of tumor angiogenesis, tumor invasiveness and metastasis [19, 21]. Further studies in the Rip-Tag2 mouse model with an anti-VEGF antibody or sunitinib in combination with the c-Met inhibitor PF-04217903 [19, 21] also showed additive antitumoral effects. The antitumoral effects of cabozantinib in the Rip-Tag2 mouse model have been discussed to be due to simultaneous inhibition of VEGF and c-Met signaling by cabozantinib $[19,21]$. However, due to the multi-TKI function of cabozantinib (with known ac- 

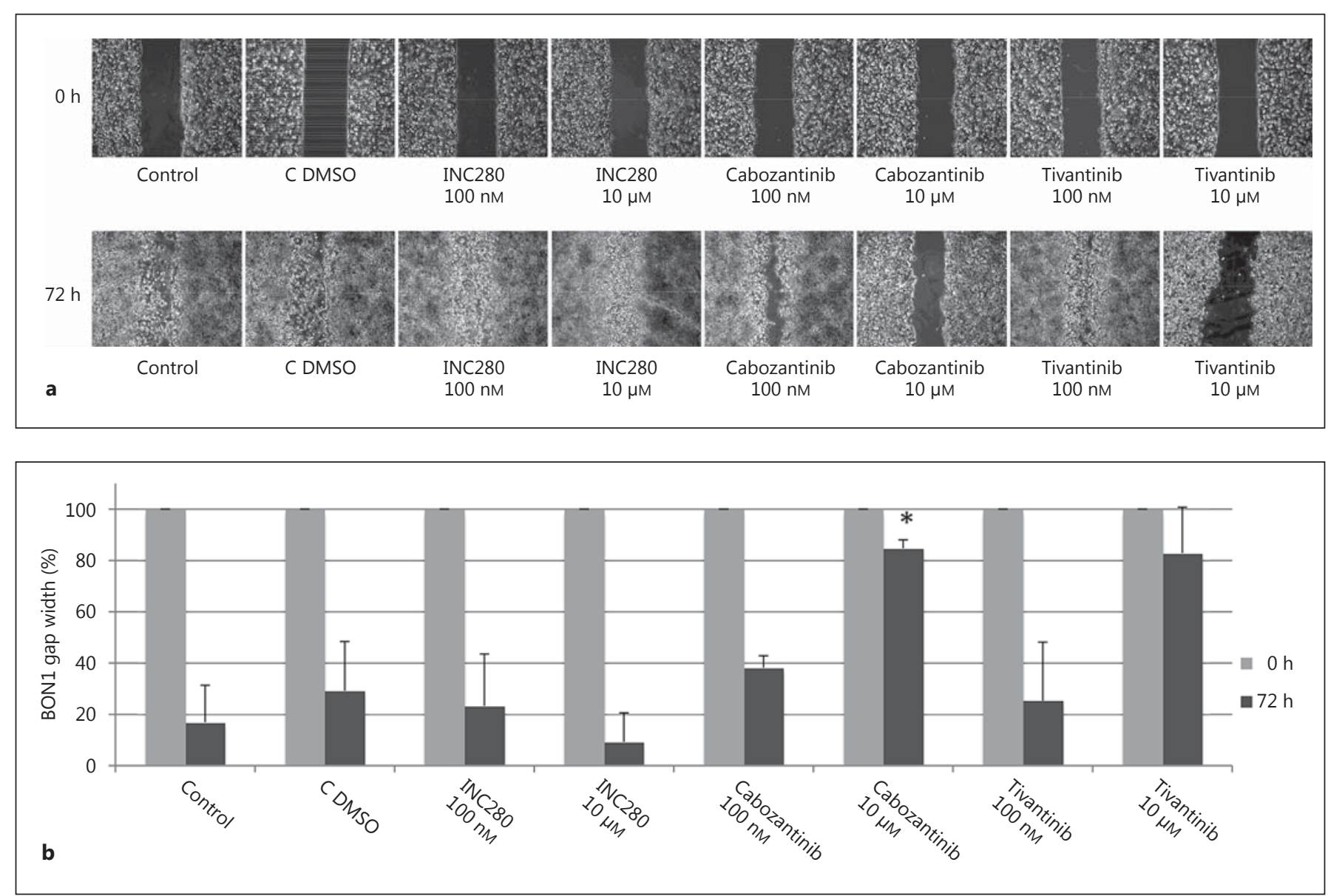

Fig. 7. Differential effects of INC280, cabozantinib and tivantinib on cell migration of neuroendocrine tumor cells. Human pancreatic neuroendocrine $\mathrm{BON} 1(\mathbf{a}, \mathbf{b})$ and bronchopulmonary NCIH727 (c, d) cells were incubated with INC280, cabozantinib and tivantinib, respectively, at a concentration of $100 \mathrm{nM}$ and $10 \mu \mathrm{M}$ for $72 \mathrm{~h}$. The gap width between the two monolayers was analyzed at
0 and $72 \mathrm{~h}$ of the incubation period, respectively. A representative experiment out of three independently performed experiments is shown $(\mathbf{a}, \mathbf{c})$. b, d The gap width at 0 and $72 \mathrm{~h}$, respectively, for each treatment group was analyzed. The mean values \pm SD of three independently performed experiments are shown. Statistical analysis with $\mathrm{t}$ test showed significant results with ${ }^{*} \mathrm{p}<0.05$ and ${ }^{* *} \mathrm{p}<0.01$.

(For figures $7 c$ and $d$ see next page.) tivity against c-Met, VEGFR2, c-KIT, FLT3, RET and TIE2), these studies cannot prove the efficacy of c-Met inhibition for the antitumoral effects of cabozantinib [19, 21]. Our in vitro data suggest that c-Met inhibition alone is not sufficient to exert direct antitumoral or antimigratory effects in unstimulated neuroendocrine tumor cells.

Nevertheless, in neuroendocrine tumor cells with compensatory upregulation of phospho-c-Met expression, inhibition of c-Met might be a specific target for antitumoral and antimigratory effects [21]. In human pancreatic cancer cells in vitro, INC280 inhibited HGFinduced cell growth and migration, while no effect of INC280 was observed on constitutive cell growth and migration in cells that were not stimulated by HGF [45]. In hepatocellular tumor cell models, cabozantinib caused a G1 arrest in the phospho-c-Met-overexpressing tumor cell lines MHCC97L and MHCC97H (cabozantinib IC 50 values for inhibition of cell growth 9-13 nM), while in the non-phospho-c-Met-expressing tumor cell lines SKHEP1 and HepG2 (cabozantinib IC 50 values for inhibition of cell growth 4,300-5,000 nM), a G2 arrest was observed [46]. These data suggest different c-Met-dependent and c-Met-independent mechanisms of cabozantinib on cell cycle in tumor cells [46].

In accordance with our results in neuroendocrine tumor cells, tivantinib has recently been reported to exert antitumoral effects in various tumor entities, which are an offtarget of c-Met inhibition [13-16]. In thyroid cancer cells, 

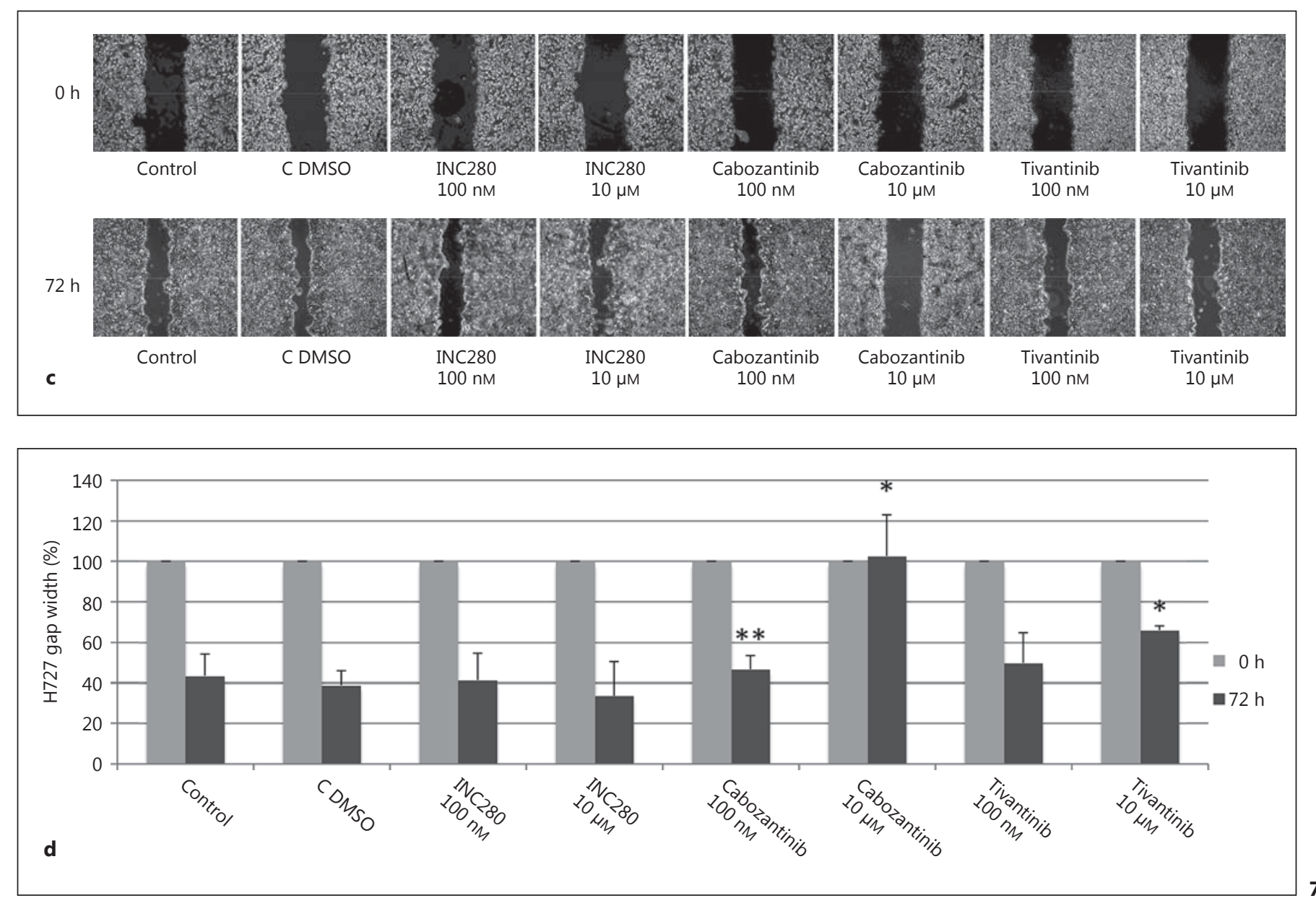

siRNA-mediated downregulation of c-Met did not induce cell cycle arrest or apoptosis [14]. There was no correlation between the c-Met inhibitory potency of crizotinib and tivantinib and their respective antitumoral efficacy in thyroid tumor cells [14]. In various tumor cell entities, tivantinib inhibited c-Met addicted and nonaddicted tumor cells in a similar fashion $[15,16]$, suggesting a c-Met-independent mechanism of action. Tivantinib has been suggested to cause antitumoral effects by alternative mechanisms as microtubule disruption $[15,16,43]$ or inhibition of GSK3 $\alpha$ and GSK3 $\beta$ [44]. Tivantinib caused a significant G2 arrest in various tumor cells [13-16], while the c-Met inhibitors crizotinib and PHA-665752 caused a G1 arrest [15].

In our neuroendocrine tumor cell model in vitro, cabozantinib and tivantinib demonstrated late-onset 72hour effects with inhibition of the expression of pEGFR (fig. 4), pAktS473 (fig. 4), p4EBP1S65 (fig. 4) and cyclin D1 (fig. 6). In addition, cabozantinib constantly induced GSK3 phosphorylation at pGSK3 S21/9 in both cell lines at $72 \mathrm{~h}$ (fig. 4). Cabozantinib and tivantinib modestly inhibited the proliferation marker PCNA at $72 \mathrm{~h}$ (fig. 6) and caused a potent $\mathrm{G} 2$ cycle arrest (fig. 5) in BON1 and $\mathrm{H} 727$ cells. These data indicate that cabozantinib and tivantinib decrease tumor cell viability, most probably due to inhibition of cell proliferation mediated by inhibition of pAkt and its downstream signals and by upregulation of pGSK3. In contrast, no PARP cleavage as a marker of apoptosis was detected (fig. 6). Accordingly, c-Met inhibitors have been reported to inhibit downstream Akt and MAPK signaling cascades in various tumors [7, 9, 46]. Inhibition of Akt/mTOR signaling is a proven, important target in neuroendocrine tumor cells $[28,30]$. The phosphorylation of GSK3 causes its inactivation [47].

Cabozantinib and tivantinib cause a G2 cycle arrest in BON1 and H727 cells (fig. 5). Accordingly to our data, a G2 arrest has also been reported in other in vitro cancer models with cabozantinib [42] and tivantinib [13-16]. Tivantinib has been reported to cause G2 cell cycle arrest in 


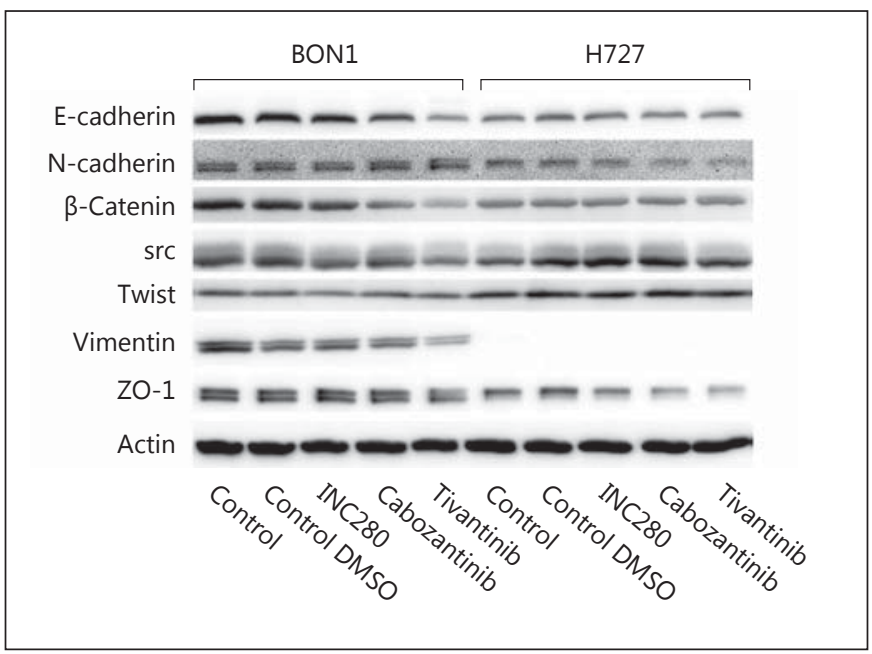

Fig. 8. Lack of effect of INC280, cabozantinib and tivantinib on EMT markers. Human pancreatic neuroendocrine BON1 and bronchopulmonary NCI-H727 cells were incubated with equimolar concentrations (10,000 nM) of INC280, cabozantinib and tivantinib, respectively, for $24 \mathrm{~h}$. Subsequently, the expression of Ecadherin, $\mathrm{N}$-cadherin, $\beta$-catenin, src, twist, vimentin, ZO- 1 and $\beta$-actin loading control was evaluated by Western blot analysis. One representative blot out of three independently performed experiments is shown.

various c-Met addicted and nonaddicted cancer cell lines and to cause microtubule disruption [15]. Phosphorylation and activation of the cell cycle G2 checkpoint regulator Chk1 is known to cause subsequent phosphorylation and inactivation of the phosphatase CDC25. Inactivation of CDC25 phosphatase prevents dephosphorylation and activation of CDK1 in the cyclin B/CDK1 complex and finally inhibits progression to mitosis [48]. On the other hand, Chk1 inhibitors have been suggested as a potential target to sensitize cancer cells [48]. The effects of cabozantinib or tivantinib on the cell cycle G2 checkpoint regulator Chk1 were different in BON1 and H727 cells (fig. 6a, b), indicating a cell type-specific regulation. Further studies are necessary to evaluate the mechanisms by which cabozantinib and tivantinib cause G2 cell cycle arrest in our neuroendocrine tumor cell model.

Our study clearly demonstrates that single c-Met inhibition with the highly specific c-Met inhibitor INC280 is not sufficient to exert direct antiproliferative effects or inhibition of tumor cell migration in neuroendocrine tumor cells in vitro under constitutive conditions. Neuroendocrine tumor cells without pretreatment were not dependent on c-Met signaling for growth, survival or migration. Thus, based on our in vitro data, it seems not to be a promising strategy to target neuroendocrine tumors in monotherapy with highly specific c-Met inhibitors. However, the limitations of an in vitro model of NET to study their tumor biology have to be stated as follows: (a) there is only a limited number of human cell lines available $[24,27]$, and (b) the cell proliferation rates of many rapidly growing cell culture models do not match the slow proliferation index Ki-67 of typical G1 and G2 NET.

In contrast, we observed potent antiproliferative effects and inhibition of tumor cell migration by the multiTKIs cabozantinib and tivantinib in neuroendocrine tumor cells in vitro. Our data suggest these in vitro effects of cabozantinib (multi-TKI with known activity against c-Met, VEGFR2, c-KIT, FLT3, RET and TIE2) and tivantinib (c-Met inhibitor with additional 'off-target' effects [13-16]) to be most likely mediated by 'off-target' effects besides c-Met. These findings may have implications for the rationale of future selection of multi-TKIs for neuroendocrine tumor treatment and for the evaluation of phospho-c-Met expression as a potential biomarker for response prediction in neuroendocrine tumors.

Single c-Met inhibition seems insufficient to exert direct antitumoral effects in unstimulated neuroendocrine tumor cells. Nevertheless, a synergistic action of c-Met inhibition during combination therapy targeting several signaling cascades cannot be excluded by our data. As stated above, in cancers with compensatory upregulation of phospho-cMet expression, inhibition of c-Met seems to exert antitumoral and antimigratory effects $[21,49]$. In other various tumor entities, resistance against EGFR inhibition or resistance against anti-VEGF therapy has been demonstrated to be mediated by compensatory upregulation of phosphorylated c-Met as an alternative signaling pathway. Inhibition of c-Met has been discussed as a potential target in combination therapies in order to overcome a c-Met-induced escape from EGFR inhibition [50-56] or escape from antiVEGF therapy [31, 57-60], as has been demonstrated in various tumor entities. These mechanisms have also been discussed for neuroendocrine tumors [19-21, 31, 61]. Further preclinical in vivo studies in xenograft models of human NET treated with appropriate combination therapies including the highly specific c-Met inhibitor INC280 should be performed to address this issue.

\section{Conclusions}

Specific inhibition of c-Met in neuroendocrine tumor cell lines under constitutive conditions in vitro did not cause antiproliferative or antimigratory effects. INC280 
is a highly selective c-MET inhibitor, and its further evaluation in c-Met-dependent tumor entities, as cancers with constitutive or compensatory upregulation of phospho-c-Met expression, is warranted.

Our in vitro data demonstrate that cabozantinib and tivantinib with potent antiproliferative effects in neuroendocrine tumors are most probably mediated by 'offtarget' effects not mediated by c-MET inhibition. Further investigation of these compounds as antitumoral agents in neuroendocrine tumors is warranted. Currently, a clinical phase 2 study of cabozantinib in neuroendocrine tumors (NCT01466036) is recruiting patients.

\section{Acknowledgements}

This work contains parts of the unpublished doctoral thesis of C. Reuther. This article was edited for proper English language, grammar, punctuation and spelling by the editors of www.proofreading-service.com.
This study has been funded by NeoExNET (Network of Excellence for Neuroendocrine Tumours in Munich). NeoExNET is a national database for the evaluation of diagnostics, treatment and outcome in neuroendocrine tumors. NeoExNET is supported by the German Federal Ministry of Education and Research (BMBF; $\mathrm{m}^{4}$ Cluster: Personalised Medicine and Targeted Therapies Leading-Edge Cluster Munich, 16EX1221J, 01EX1020E) and by an unrestricted educational grant from Novartis Pharma GmbH, Nuremberg, Germany. Members of the NeoExNET study group include: principal investigator: Günter K. Stalla (Max Planck Institute of Psychiatry, Munich); steering committee: Felix Beuschlein (Ludwig Maximilian University, Munich), Christoph Auernhammer (Ludwig Maximilian University, Munich) and Klaus A. Kuhn (Technische Universität München, Munich).

\section{Disclosure Statement}

C.J.A. has received research contracts (Ipsen, Novartis), lecture honoraria (Ipsen, Novartis, Pfizer, Amgen, Roche, Falk) and an advisory board honorarium (Novartis). The authors declare that there is no conflict of interest that would prejudice the impartiality of this scientific work.

\section{References}

1 Frilling A, Akerström G, Falconi M, Pavel M, Ramos J, Kidd M, Modlin IM: Neuroendocrine tumor disease: an evolving landscape. Endocr Relat Cancer 2012;19:R163-R185.

- 2 Yao JC, Shah MH, Ito T, Bohas CL, Wolin EM, Van Cutsem E, Hobday TJ, Okusaka T, Capdevila J, de Vries EG, Tomassetti P, Pavel ME, Hoosen S, Haas T, Lincy J, Lebwohl D, Öberg K; RAD001 in Advanced Neuroendocrine Tumors, Third Trial (RADIANT-3) Study Group: Everolimus for advanced pancreatic neuroendocrine tumors. N Engl J Med 2011;364:514-523.

-3 Pavel ME, Hainsworth JD, Baudin E, Peeters M, Hörsch D, Winkler RE, Klimovsky J, Lebwohl D, Jehl V, Wolin EM, Oberg K, Van Cutsem E, Yao JC; RADIANT-2 Study Group: Everolimus plus octreotide long-acting repeatable for the treatment of advanced neuroendocrine tumours associated with carcinoid syndrome (RADIANT-2): a randomised, placebo-controlled, phase 3 study. Lancet 2011; 378:2005-2012.

4 Raymond E, Dahan L, Raoul JL, Bang YJ, Borbath I, Lombard-Bohas C, Valle J, Metrakos P, Smith D, Vinik A, Chen JS, Hörsch D, Hammel P, Wiedenmann B, Van Cutsem E, Patyna S, Lu DR, Blanckmeister C, Chao R, Ruszniewski P: Sunitinib malate for the treatment of pancreatic neuroendocrine tumors. N Engl J Med 2011;364:501-513.
-5 Auernhammer CJ, Göke B: Therapeutic strategies for advanced neuroendocrine carcinomas of jejunum/ileum and pancreatic origin. Gut 2011;60:1009-1021.

-6 Raymond E, García-Carbonero R, Wiedenmann B, Grande E, Pavel M: Systemic therapeutic strategies for GEP-NETS: what can we expect in the future? Cancer Metastasis Rev 2014;33:367-372.

7 Blumenschein GR Jr, Mills GB, Gonzalez-Angulo AM: Targeting the hepatocyte growth factor-cMET axis in cancer therapy. J Clin Oncol 2012;30:3287-3296.

-8 Scagliotti GV, Novello S, von Pawel J: The emerging role of $\mathrm{MET} / \mathrm{HGF}$ inhibitors in oncology. Cancer Treat Rev 2013;39:793801.

-9 Parikh RA, Wang P, Beumer JH, Chu E, Appleman LJ: The potential roles of hepatocyte growth factor (HGF)-MET pathway inhibitors in cancer treatment. Onco Targets Ther 2014;7:969-983.

10 Smyth EC, Sclafani F, Cunningham D: Emerging molecular targets in oncology: clinical potential of MET/hepatocyte growth-factor inhibitors. Onco Targets Ther 2014;7: 1001-1014.

11 Elisei R, Schlumberger MJ, Müller SP, Schöffski P, Brose MS, Shah MH, Licitra L, Jarzab B, Medvedev V, Kreissl MC, Niederle B, Cohen EE, Wirth LJ, Ali H, Hessel C, Yaron Y, Ball D, Nelkin B, Sherman SI: Cabozantinib in progressive medullary thyroid cancer. J Clin Oncol 2013;31:3639-3646.
12 Bentzien F, Zuzow M, Heald N, Gibson A, Shi Y, Goon L, Yu P, Engst S, Zhang W, Huang D, Zhao L, Vysotskaia V, Chu F, Bautista R, Cancilla B, Lamb P, Joly AH, Yakes FM: In vitro and in vivo activity of cabozantinib (XL184), an inhibitor of RET, MET, and VEGFR2, in a model of medullary thyroid cancer. Thyroid 2013;23:1569-1577.

-13 Calles A, Kwiatkowski N, Cammarata BK, Ercan D, Gray NS, Jänne PA: Tivantinib (ARQ 197) efficacy is independent of MET inhibition in non-small-cell lung cancer cell lines. Mol Oncol 2015;9:260-269.

14 Zhou Y, Zhao C, Gery S, Braunstein GD, Okamoto R, Alvarez R, Miles SA, Doan NB, Said JW, Gu J, Phillip Koeffler H: Off-target effects of c-MET inhibitors on thyroid cancer cells. Mol Cancer Ther 2014;13:134-143.

15 Katayama R1, Aoyama A, Yamori T, Qi J, Ohhara T, Song Y, Engelman JA, Fujita N: Cytotoxic activity of tivantinib (ARQ 197) is not due solely to c-MET inhibition. Cancer Res 2013;73:3087-3096.

-16 Basilico C, Pennacchietti S, Vigna E, Chiriaco C, Arena S, Bardelli A, Valdembri D, Serini G, Michieli P: Tivantinib (ARQ197) displays cytotoxic activity that is independent of its ability to bind MET. Clin Cancer Res 2013;19: 2381-2392.

17 Santoro A, Rimassa L, Borbath I, et al: Tivantinib for second-line treatment of advanced hepatocellular carcinoma: a randomised, placebo-controlled phase 2 study. Lancet Oncol 2013;14:55-63. 
$\longrightarrow 18$ Sequist LV, von Pawel J, Garmey EG, Akerley WL, Brugger W, Ferrari D, Chen Y, Costa DB, Gerber DE, Orlov S, Ramlau R, Arthur S, Gorbachevsky I, Schwartz B, Schiller JH: Randomized phase II study of erlotinib plus tivantinib versus erlotinib plus placebo in previously treated non-small-cell lung cancer. J Clin Oncol 2011;29:3307-3315.

-19 You WK, Sennino B, Williamson CW, Falcón B, Hashizume H, Yao LC, Aftab DT, McDonald DM: VEGF and c-Met blockade amplify angiogenesis inhibition in pancreatic islet cancer. Cancer Res 2011;71:4758-4768.

-20 Sennino B, Ishiguro-Oonuma T, Schriver BJ, Christensen JG, McDonald DM: Inhibition of c-Met reduces lymphatic metastasis in RIPTag2 transgenic mice. Cancer Res 2013;73: 3692-3703.

-21 Sennino B, Ishiguro-Oonuma T, Wei Y, Naylor RM, Williamson CW, Bhagwandin V, Tabruyn SP, You WK, Chapman HA, Christensen JG, Aftab DT, McDonald DM: Suppression of tumor invasion and metastasis by concurrent inhibition of c-Met and VEGF signaling in pancreatic neuroendocrine tumors. Cancer Discov 2012;2:270-287.

-22 Spampatti M, Vlotides G, Spöttl G, Maurer J, Göke B, Auernhammer CJ: Aspirin inhibits cell viability and mTOR downstream signaling in gastroenteropancreatic and bronchopulmonary neuroendocrine tumor cells. World J Gastroenterol 2014;20:10038-10049.

-23 Evers BM, Townsend CM Jr, Upp JR, Allen E, Hurlbut SC, Kim SW, Rajaraman S, Singh P, Reubi JC, Thompson JC: Establishment and characterization of a human carcinoid in nude mice and effect of various agents on tumor growth. Gastroenterology 1991;101:303311.

24 Babu V, Paul N, Yu R: Animal models and cell lines of pancreatic neuroendocrine tumors. Pancreas 2013;42:912-923.

25 Kölby L, Bernhardt P, Ahlman H, Wängberg B, Johanson V, Wigander A, Forssell-Aronsson E, Karlsson S, Ahrén B, Stenman G, Nilsson O: A transplantable human carcinoid as model for somatostatin receptor-mediated and amine transporter-mediated radionuclide uptake. Am J Pathol 2001;158:745-755.

-26 Schuller HM, Falzon M, Gazdar AF, Hegedus $\mathrm{T}$ : Cell type-specific differences in metabolic activation of $\mathrm{N}$-nitrosodiethylamine by human lung cancer cell lines. IARC Sci Publ 1987;84:138-140.

27 Cakir M, Grossman A: The molecular pathogenesis and management of bronchial carcinoids. Expert Opin Ther Targets 2011;15: 457-491.

28 Zitzmann K, Vlotides G, Brand S, Lahm H, Spöttl G, Göke B, Auernhammer CJ: Perifosine-mediated Akt inhibition in neuroendocrine tumor cells: role of specific Akt isoforms. Endocr Relat Cancer 2012;19:423434.
9 Zitzmann K, De Toni EN, Brand S, Göke B, Meinecke J, Spöttl G, Meyer HH, Auernhammer CJ: The novel mTOR inhibitor RAD001 (everolimus) induces antiproliferative effects in human pancreatic neuroendocrine tumor cells. Neuroendocrinology 2007;85:54-60.

30 Zitzmann K, Rüden Jv, Brand S, Göke B, Lichtl J, Spöttl G, Auernhammer CJ: Compensatory activation of Akt in response to mTOR and Raf inhibitors - a rationale for dual-targeted therapy approaches in neuroendocrine tumor disease. Cancer Lett 2010; 295:100-109.

31 De Dosso S, Grande E, Barriuso J, Castellano D, Tabernero J, Capdevila J: The targeted therapy revolution in neuroendocrine tumors: in search of biomarkers for patient selection and response evaluation. Cancer Metastasis Rev 2013;32:465-477.

32 Modali SD, Parekh VI, Kebebew E, Agarwal SK: Epigenetic regulation of the lncRNA MEG3 and its target c-MET in pancreatic neuroendocrine tumors. Mol Endocrinol 2015;29:224-237.

- 33 Hansel DE, Rahman A, House M, Ashfaq R, Berg K, Yeo CJ, Maitra A: Met proto-oncogene and insulin-like growth factor binding protein 3 overexpression correlates with metastatic ability in well-differentiated pancreatic endocrine neoplasms. Clin Cancer Res 2004; 10:6152-6158.

34 Hofsli E, Thommesen L, Yadetie F, Langaas M, Kusnierczyk W, Falkmer U, Sandvik AK, Laegreid A: Identification of novel growth factor-responsive genes in neuroendocrine gastrointestinal tumour cells. Br J Cancer 2005;92:1506-1516.

- 35 Peghini PL, Iwamoto M, Raffeld M, Chen YJ, Goebel SU, Serrano J, Jensen RT: Overexpression of epidermal growth factor and hepatocyte growth factor receptors in a proportion of gastrinomas correlates with aggressive growth and lower curability. Clin Cancer Res 2002;8:2273-2285.

36 Azzoni C, Bottarelli L, Cecchini S, Lagrasta C, Pizzi S, D’Adda T, Tamburini E, Rindi G, Bordi C: Involvement of HER-2/neu and metastasis-related proteins in the development of ileal neuroendocrine tumors. Virchows Arch 2011;458:525-536.

37 Van Buren G 2nd, Rashid A, Yang AD, Abdalla EK, Gray MJ, Liu W, Somcio R, Fan F, Camp ER, Yao JC, Ellis LM: The development and characterization of a human midgut carcinoid cell line. Clin Cancer Res 2007;13: 4704-4712.

38 Song J, Li M, Tretiakova M, Salgia R, Cagle PT, Husain AN: Expression patterns of PAX5, c-Met, and paxillin in neuroendocrine tumors of the lung. Arch Pathol Lab Med 2010; 134:1702-1705.

39 Voortman J, Harada T, Chang RP, Killian JK, Suuriniemi M, Smith WI, Meltzer PS, Lucchi M, Wang Y, Giaccone G: Detection and therapeutic implications of c-Met mutations in small cell lung cancer and neuroendocrine tumors. Curr Pharm Des 2013;19:833-840.
40 Telega A, Kos-Kudła B, Foltyn W, BlicharzDorniak J, Rosiek V: Selected neuroendocrine tumour markers, growth factors and their receptors in typical and atypical bronchopulmonary carcinoids. Endokrynol Pol 2012;63: 477-482.

41 Liu X, Wang Q, Yang G, Marando C, Koblish HK, Hall LM, Fridman JS, Behshad E, Wynn R, Li Y, Boer J, Diamond S, He C, Xu M, Zhuo J, Yao W, Newton RC, Scherle PA: A novel kinase inhibitor, INCB28060, blocks c-METdependent signaling, neoplastic activities, and cross-talk with EGFR and HER-3. Clin Cancer Res 2011;17:7127-7138.

42 Yakes FM, Chen J, Tan J, Yamaguchi K, Shi Y, Yu P, Qian F, Chu F, Bentzien F, Cancilla B, Orf J, You A, Laird AD, Engst S, Lee L, Lesch J, Chou YC, Joly AH: Cabozantinib (XL184), a novel MET and VEGFR2 inhibitor, simultaneously suppresses metastasis, angiogenesis, and tumor growth. Mol Cancer Ther 2011;10: 2298-2308.

43 Munshi N, Jeay S, Li Y, Chen CR, France DS, Ashwell MA, Hill J, Moussa MM, Leggett DS, Li CJ: ARQ 197, a novel and selective inhibitor of the human c-Met receptor tyrosine kinase with antitumor activity. Mol Cancer Ther 2010;9:1544-1553.

44 Imura Y, Yasui H, Outani H, Wakamatsu T, Hamada K, Nakai T, Yamada S, Myoui A, Araki N, Ueda T, Itoh K, Yoshikawa H, Naka $\mathrm{N}$ : Combined targeting of mTOR and c-MET signaling pathways for effective management of epithelioid sarcoma. Mol Cancer 2014;13: 185.

45 Brandes F, Schmidt K, Wagner C, Redekopf J, Schlitt HJ, Geissler EK, Lang SA: Targeting cMET with INC280 impairs tumour growth and improves efficacy of gemcitabine in a pancreatic cancer model. BMC Cancer 2015; 15:71.

46 Xiang Q, Chen W, Ren M, Wang J, Zhang H, Deng DY, Zhang L, Shang C, Chen Y: Cabozantinib suppresses tumor growth and metastasis in hepatocellular carcinoma by a dual blockade of VEGFR2 and MET. Clin Cancer Res 2014;20:2959-2970.

47 McCubrey JA, Steelman LS, Bertrand FE, Davis NM, Sokolosky M, Abrams SL, Montalto G, D'Assoro AB, Libra M, Nicoletti F, Maestro R, Basecke J, Rakus D, Gizak A, Demidenko ZN, Cocco L, Martelli AM, Cervello M: GSK-3 as potential target for therapeutic intervention in cancer. Oncotarget 2014;5: 2881-2911.

48 Thompson R, Eastman A: The cancer therapeutic potential of Chk1 inhibitors: how mechanistic studies impact on clinical trial design. Br J Clin Pharmacol 2013;76:358-369.

49 Aoyama A, Katayama R, Oh-Hara T, Sato S, Okuno Y, Fujita N: Tivantinib (ARQ 197) exhibits antitumor activity by directly interacting with tubulin and overcomes $\mathrm{ABC}$ transporter-mediated drug resistance. Mol Cancer Ther 2014;13:2978-2990. 
50 Remsing Rix LL, Kuenzi BM, Luo Y, RemilyWood E, Kinose F, Wright G, Li J, Koomen JM, Haura EB, Lawrence HR, Rix U: GSK3 alpha and beta are new functionally relevant targets of tivantinib in lung cancer cells. ACS Chem Biol 2014;9:353-358.

-51 Bardelli A, Corso S, Bertotti A, et al: Amplification of the MET receptor drives resistance to anti-EGFR therapies in colorectal cancer. Cancer Discov 2013;3:658-673.

52 Castoldi R1 Ecker V, Wiehle L, Majety M, Busl-Schuller R, Asmussen M, Nopora A, Jucknischke U, Osl F, Kobold S, Scheuer W, Venturi M, Klein C, Niederfellner G, Sustmann C: A novel bispecific EGFR/Met antibody blocks tumor-promoting phenotypic effects induced by resistance to EGFR inhibition and has potent antitumor activity. Oncogene 2013;32:5593-5601.

-53 Jun HJ, Bronson RT, Charest A: Inhibition of EGFR induces a c-MET-driven stem cell population in glioblastoma. Stem Cells 2014;32: 338-348.
54 Karamouzis MV, Konstantinopoulos PA, Papavassiliou AG: Targeting MET as a strategy to overcome crosstalk-related resistance to EGFR inhibitors. Lancet Oncol 2009; 10:709717.

55 Luraghi P, Reato G, Cipriano E, Sassi F, Orzan F, Bigatto V, De Bacco F, Menietti E, Han M, Rideout WM 3rd, Perera T, Bertotti A, Trusolino L, Comoglio PM, Boccaccio C: MET signaling in colon cancer stem-like cells blunts the therapeutic response to EGFR inhibitors. Cancer Res 2014;74:1857-1869.

56 Xu H, Stabile LP, Gubish CT, Gooding WE, Grandis JR, Siegfried JM: Dual blockade of EGFR and c-Met abrogates redundant signaling and proliferation in head and neck carcinoma cells. Clin Cancer Res 2011;17:44254438.

57 McCarty JH: Glioblastoma resistance to antiVEGF therapy: has the challenge been MET? Clin Cancer Res 2013;19:1631-1633.
58 Jahangiri A, De Lay M, Miller LM, Carbonell WS, Hu YL, Lu K, Tom MW, Paquette J, Tokuyasu TA, Tsao S, Marshall R, Perry A, Bjorgan KM, Chaumeil MM, Ronen SM, Bergers G, Aghi MK: Gene expression profile identifies tyrosine kinase c-Met as a targetable mediator of antiangiogenic therapy resistance. Clin Cancer Res 2013;19:1773-1783.

59 Shojaei F, Lee JH, Simmons BH, Wong A, Esparza CO, Plumlee PA, Feng J, Stewart AE, Hu-Lowe DD, Christensen JG: HGF/c-Met acts as an alternative angiogenic pathway in sunitinib-resistant tumors. Cancer Res 2010; 70:10090-10100.

60 Shojaei F, Simmons BH, Lee JH, Lappin PB, Christensen JG: $\mathrm{HGF} / \mathrm{c}-$ Met pathway is one of the mediators of sunitinib-induced tumor cell type-dependent metastasis. Cancer Lett 2012; 320:48-55.

61 Oberg K, Casanovas O, Castaño JP, Chung D, Delle Fave G, Denèfle P, Harris P, Khan MS, Kulke MH, Scarpa A, Tang LH, Wiedenmann B: Molecular pathogenesis of neuroendocrine tumors: implications for current and future therapeutic approaches. Clin Cancer Res 2013;19:2842-2849. 